Hydrology and Earth System Sciences, 6(3), 433-453 (2002) C EGS

\title{
Modelling nitrogen dynamics and distributions in the River Tweed, Scotland: an application of the INCA model
}

\author{
H.P. Jarvie ${ }^{1}$, A.J. Wade 2 , D. Butterfield ${ }^{2}$, P.G. Whitehead ${ }^{2}$, C.I. Tindal1 ${ }^{1}$, W.A. Virtue ${ }^{3}$, \\ W. Dryburgh ${ }^{3}$ and A. McGraw ${ }^{3}$ \\ ${ }^{1}$ Centre for Ecology and Hydrology, Wallingford, OX10 8BB, UK \\ ${ }^{2}$ Aquatic Environments Research Centre, University of Reading. RG6 6AB, UK \\ ${ }^{3}$ Scottish Environment Protection Agency, Burnbrae, Mossilee Road, Galashiels, TD1 1NF, UK
}

Email for corresponding author: hpj@ceh.ac.uk

\begin{abstract}
The INCA (Integrated Nitrogen in Catchments) model was applied to the River Tweed in the Scottish Borders, a large-scale $\left(4400 \mathrm{~km}^{2}\right)$, spatially heterogeneous catchment, draining a wide range of agricultural land-use types, and which contributes approximately $20 \%$ of UK river flows to the North Sea. The model was calibrated for the first four years' data record (1994 to 1997) and tested over the following three years (1998 to 2000). The model calibration and testing periods incorporated a high degree of variability in climatic conditions and river flows within the Tweed catchment. The ability of the INCA model to reproduce broad-scale spatial patterns and seasonal dynamics in river flows and nitrate concentrations suggests that the processes controlling first order variability in river water nitrate concentrations have been represented successfully within the model. The tendency of the model to overestimate summer/early autumn baseflow nitrate concentrations during dry years may be linked to the operation of aquatic plant uptake effects. It is, therefore, suggested that consideration be given to incorporating a spatially and temporally variable in-stream plant uptake term for the application of INCA to lowland eutrophic rivers. Scenarios to examine possible impacts of environmental change on nitrate concentrations on the Tweed are examined. These include the effects of (i) implementing different recommendations for fertiliser use and land use change under the Nitrate Sensitive Areas (NSA) Scheme and the Scottish Code of Good Agricultural Practice, (ii) worst case scenario changes linked to a dramatic reduction in livestock numbers as a result of a crisis in UK livestock farming and (iii) changes in atmospheric nitrogen deposition.
\end{abstract}

Keywords: Nitrate, nitrogen, modelling, Tweed, INCA

\section{Introduction}

Nitrogen $(\mathrm{N})$, in combination with phosphorus $(\mathrm{P})$, plays an important role in controlling the trophic status of surface waters. Increasing loadings of $\mathrm{N}$ and $\mathrm{P}$ from anthropogenic activity (agriculture, wastewater disposal and atmospheric emissions) have resulted in widespread enrichment of nutrients in surface waters and associated problems of eutrophication linked to excessive accumulation of phytoplankton/filamentous algal biomass, toxic algal blooms and dissolved oxygen depletion. Eutrophication is most visibly apparent in lowland rivers which tend to receive greatest nitrogen inputs from agriculture and effluent, and exhibit higher in-stream nutrient concentrations than upland streams. However, there are growing concerns about the nutrient status of upland streams and their sensitivity to acidification and changes in trophic status (Neal, 2002). Nitrogen saturation (whereby deposition exceeds biotic demand (Emmett et al., 1995; Stoddart, 1994)) is a growing concern in upland catchments, linked to increasing $\mathrm{N}$ inputs from atmospheric deposition (Fowler et al., 1989) and enhanced rates of $\mathrm{N}$ leaching from forestry (Emmett et al., 1993; Dise and Wright, 1995).

Various strategies are employed to control $\mathrm{N}$ inputs to rivers at the national (UK) and European levels. A major instrument for control of $\mathrm{N}$ losses to surface and groundwaters is the 1992 European Nitrate Directive, which focuses on prevention at source and provides recommendations for changes in agricultural practice and land use. In the UK, the Nitrate Sensitive Areas scheme introduced by the Ministry for Agriculture, Fisheries and 
Food (MAFF, 1989) and the Code of Good Agricultural Practice (MAFF/WOAD, 1991; Scottish Office, 1997) provide specific guidelines to farmers to minimise losses of $\mathrm{N}$ from agricultural land, and are discussed further by Parkinson (1993) and Ball (1993). However, the combined impact of these policies on controlling nitrogen pollution in rivers is uncertain.

Nitrate is the predominant form of nitrogen transported in rivers and is derived from a wide variety of sources within catchments: fertilisers, sewage and industrial effluents, atmospheric inputs and mineralisation and nitrification of organic nitrogen in soils (Stewart et al., 1982; Heathwaite et al., 1996). The release of nitrate and subsequent transport, exchanges and transformations within the catchment and stream network are controlled by a complex set of biological, physical and chemical processes, which are highly variable in both space and time. Water quality models provide simplified representation of this highly complex system in order to assess and analyse source contributions and flux modifications in catchments (e.g. MAGIC, Cosby et al., 1985a,b; MERLIN, Cosby et al., 1997) and in rivers (e.g. QUASAR, Whitehead et al., 1997). The INCA model (Integrated Nitrogen Model for Multiple Source Assessment in Catchments), used in this study, integrates both catchment delivery of nitrogen and nitrogen transport and transformation along river reaches within one model (Whitehead et al., 1998a,b; Wade et al., 2002). By simulating sources and processes controlling $\mathrm{N}$ delivery and transport, models can provide valuable tools for catchment management and policy decision-making. Models can be used to assess possible impacts of measures aimed at reducing and managing nitrogen in river systems.

INCA models the delivery and transport of $\mathrm{N}$ through the catchment-river continuum, incorporating hydrological and biogeochemical processes. INCA is designed to be applied at scales appropriate for catchment management and utilises readily-available land use and hydrological data to simulate mean daily soil $\mathrm{N}$ leaching loads.

The River Tweed provides a valuable case study for examining $\mathrm{N}$ sources and dynamics within the coupled catchment delivery and river reach modelling framework of INCA. The Tweed is a major river system and drains a largely rural catchment, in contrast to some of the other UK and European rivers draining into the North Sea, which have highly populated and industrialised catchments, and thus carry greater pollutant loads (Robson and Neal, 1997; Jarvie et al., 1998). The Tweed catchment, which covers an area of $4400 \mathrm{~km}^{2}$, is characterised by large spatial variability in both physiographic setting, hydrology, land use and nitrate concentrations: from upland areas in the west, which are dominated by high rainfall, moorland and rough grazing land, to the intensively farmed arable lowland areas of the eastern catchment. The River Tweed is of national ecological importance and was designated a Site of Special Scientific Interest in 1976. This designation recognises that the Tweed represents (i) a nationally important example of a nutrient rich river system, with characteristic hydrological and biological sequences (ii) one of the least polluted of the easterly flowing large eutrophic British rivers (iii) the northern distribution limit of certain plant species in Britain and (iv) one of the most important salmon fisheries in the UK (Clayton, 1997). A wealth of water quality data also exists for the River Tweed, which have been used for application of the INCA model (Table 1). Long-term routine monitoring data have been collected by the Scottish Environment Protection Agency (SEPA) and the Tweed has also been a focus within a major UK community research programme, the Land Ocean Interaction Study (LOIS), with detailed water quality studies at key river sites undertaken between 1994 and 1997 (Robson and Neal, 1997; Neal et al., 1997).

The major objectives of this study were as follows:

1. To examine the ability of INCA to model the river water nitrate dynamics and variability across the large-scale and spatially heterogeneous Tweed catchment for a seven year time period (1994 to 2000), which was characterised by large variability in river flow and climatic conditions.

2. To examine the relative contributions of nitrate from different land uses and point sources through time and along a $160 \mathrm{~km}$ river continuum from the upland headwaters to the lowland input to the coastal zone.

3. To simulate the impact of possible land use change scenarios in the Scottish Borders region (linked to current changes in agricultural practices and nitrate control guidelines detailed in the Scottish Code of Good Agricultural Practice (Scottish Office, 1997)).

4. To examine the effects of changes in atmospheric nitrogen deposition on in-stream nitrate concentrations.

\section{The Tweed catchment}

The characteristics of the Tweed catchment are described in detail in Robson et al. (1996) and Robson and Neal (1997). The Tweed drains eastern slopes of the Scottish Southern Uplands, with elevations ranging from $800 \mathrm{~m}$ to sea level. Mean annual rainfall across the catchment for 1969 to 1996 was $990 \mathrm{~mm}$ (Institute of Hydrology, 1998). 
Table 1. Summary of data used in INCA modelling of the River Tweed

\begin{tabular}{|c|c|c|c|}
\hline Data & Description & Source of data & Reference \\
\hline $\begin{array}{l}\text { Streamwater } \mathrm{NO}_{3}-\mathrm{N} \text { and } \mathrm{NH}_{4}-\mathrm{N} \\
\text { concentrations }\end{array}$ & $\begin{array}{l}\text { Spot samples from } 12 \text { sites } \\
\text { along the main stem of the } \\
\text { River Tweed. Weekly to } \\
\text { monthly sampling for } \\
1994 \text { - } 2000\end{array}$ & SEPA & \\
\hline $\begin{array}{l}\text { Streamwater } \mathrm{NO}_{3}-\mathrm{N} \text { and } \mathrm{NH}_{4}-\mathrm{N} \\
\text { concentrations }\end{array}$ & $\begin{array}{l}\text { LOIS weekly sampling at } \\
\text { Boleside (Reach 12) and } \\
\text { Norham (Reach 23) for } \\
1994 \text { to } 1996\end{array}$ & $\begin{array}{l}\text { NERC Land Ocean } \\
\text { Interaction Study - LOIS } \\
\text { database }\end{array}$ & Leeks et al. (1997) \\
\hline $\begin{array}{l}\text { Effluent } \mathrm{NO}_{3}-\mathrm{N} \text { and } \mathrm{NH}_{4}-\mathrm{N} \\
\text { concentrations and flow }\end{array}$ & $\begin{array}{l}\text { Intermittent spot samples } \\
\text { used to calculate mean daily } \\
\text { flows and concentrations } \\
\text { (assumed to be constant } \\
\text { through the year) }\end{array}$ & SEPA & \\
\hline River flows & $\begin{array}{l}\text { Mean daily flows for six } \\
\text { gauging stations on the main } \\
\text { stem of the Tweed } \\
(1994-2000)\end{array}$ & $\begin{array}{l}\text { National River Flow } \\
\text { Archive }\end{array}$ & Institute of Hydrology (1998) \\
\hline $\begin{array}{l}\text { MORECS rainfall, temperature } \\
\text { and soil moisture deficit }\end{array}$ & Derived daily time series & Meteorological Office & Meteorological Office, (1981) \\
\hline Base Flow Index & $\begin{array}{l}\text { Derived for each flow gauging } \\
\text { station and extrapolated to } \\
\text { ungauged river reaches }\end{array}$ & Institute of Hydrology & Institute of Hydrology (1998) \\
\hline Fertiliser application rates & & $\begin{array}{l}\text { Survey of British Fertiliser } \\
\text { Practice }\end{array}$ & $\begin{array}{l}\text { Fertiliser Manufacturers } \\
\text { Association }\end{array}$ \\
\hline
\end{tabular}

However, as a result of the topographic variations, there is a high degree of variation in rainfall across the catchment, ranging from mean annual rainfall of $1892 \mathrm{~mm}$ in the uplands to $650 \mathrm{~mm}$ in the low-lying eastern part of the catchment (Institute of Hydrology, 1998). The land cover ranges from heather moorlands and rough grazing on the hills, improved pastures on the lower slopes to arable land in the lowlands. The main arable crops are barley, wheat, oats, oilseed rape and potatoes. Conifer plantations occupy about $16 \%$ of the land, and are located primarily on the hills in the south and west of the catchment. The geology of the Tweed catchment is predominantly sedimentary and metamorphosed sedimentary rocks (Ordovician and Silurian greywackes, shales and mudstones; old red sandstones, carboniferous shales, greywackes and limestones), with some granitic igneous intrusions and extrusive basic lava rocks in the Cheviot Hills to the south of the catchment. Soils in the lowlands are well-drained brown earths, with podzols on the higher land and peats and gleys on hilltops and the southern slopes. The Tweed catchment is sparsely populated, with an average population density of 22 people $\mathrm{km}^{-2}$, less than a tenth of the UK average. Centres of population are concentrated in a few small towns (Hawick, population 16 000; Galashiels, population 14000 , and Selkirk, population 6000). The Tweed catchment has been subject to significant agricultural change during 2001, in terms of livestock farming. The Scottish borders area has seen large-scale livestock culling in response to a serious outbreak of Foot and Mouth Disease. Over 100000 animals were slaughtered on 117 farms within the Tweed catchment between March and September 2001, although many of the farms have now been restocked, indicating that the effects 
of the Foot and Mouth crisis may be relatively short-lived. However, this recent outbreak has followed a series of profound threats to UK livestock farming, which have included BSE (Bovine Spongiform Encephalopathy or 'Mad Cow Disease'), and, with meat export restrictions in place the long-term economic future of livestock farming systems in areas such as the Scottish Borders is uncertain. These economic drivers may have an important impact on land use change within the Tweed catchment, and need to be considered when designing land use change scenarios for the nitrogen modelling exercise.

Nitrate accounts for approximately $97 \%$ of dissolved inorganic nitrogen (DIN) in the River Tweed, whereas nitrite and ammonium account for only $1.3 \%$ and $1.5 \%$ of DIN respectively (Jarvie et al., 1998). Organic forms of nitrogen can provide an important contribution to dissolved nitrogen fluxes, particularly in the upland regions of the Tweed catchment during the summer (up to $37 \%$ total nitrogen fluxes, Chapman et al., 2001). However, organic nitrogen has not been measured routinely by SEPA or under the LOIS programme and thus the data availability is sparse. Figure 1 shows the distribution of river water $\mathrm{NO}_{3}-\mathrm{N}$ concentrations across the Tweed catchment. The distribution of $\mathrm{NO}_{3}-\mathrm{N}$ shows highest concentrations in the eastern lowland parts of the catchment, which correspond with arable land use. However, elevated $\mathrm{NO}_{3}-\mathrm{N}$ concentrations are also found in some smaller tributaries in the west of the region, linked to sewage inputs and relatively low dilution capacity of small headwater streams.

Concern about nitrogen inputs to the River Tweed and its estuary has been growing over the last few years, with the prospect of nitrate vulnerable zones being designated within the eastern part of the catchment. Attention has also focused on eutrophication within the Lindisfarne National Nature Reserve, an important European site. Linkages between eutrophication in the coastal waters around Lindisfarne and nitrate discharged from the Tweed have been suggested, and investigations are continuing.

\section{Model setup}

To model nitrogen in the River Tweed, using INCA, the main stem of the River Tweed was sub-divided into 23 reaches, of less than $10 \mathrm{~km}$ in length (Table 2). Reach boundaries were designed to coincide with key factors controlling flow and water quality, such as sub-catchment tributary inputs, effluent discharges, and the location of flow gauging stations and water quality monitoring sites (Fig. 2 ). The location of gauging stations and water quality monitoring sites at reach boundaries facilitates comparison of model simulations with observed flow and chemical concentration data at specified sites along the river.

The data used to set up the INCA model for the Tweed and for calibration are outlined in Tables 1 to 3. The data required for application of INCA include mean daily river flow, streamwater nitrate (as nitrogen, $\mathrm{NO}_{3}-\mathrm{N}$ ) and ammonium (as nitrogen, $\mathrm{NH}_{4}-\mathrm{N}$ ) concentrations, and loads from major land use and vegetation types within the catchment, (Whitehead et al., 1998a,b; Wade et al, 1999, 2001, 2002).
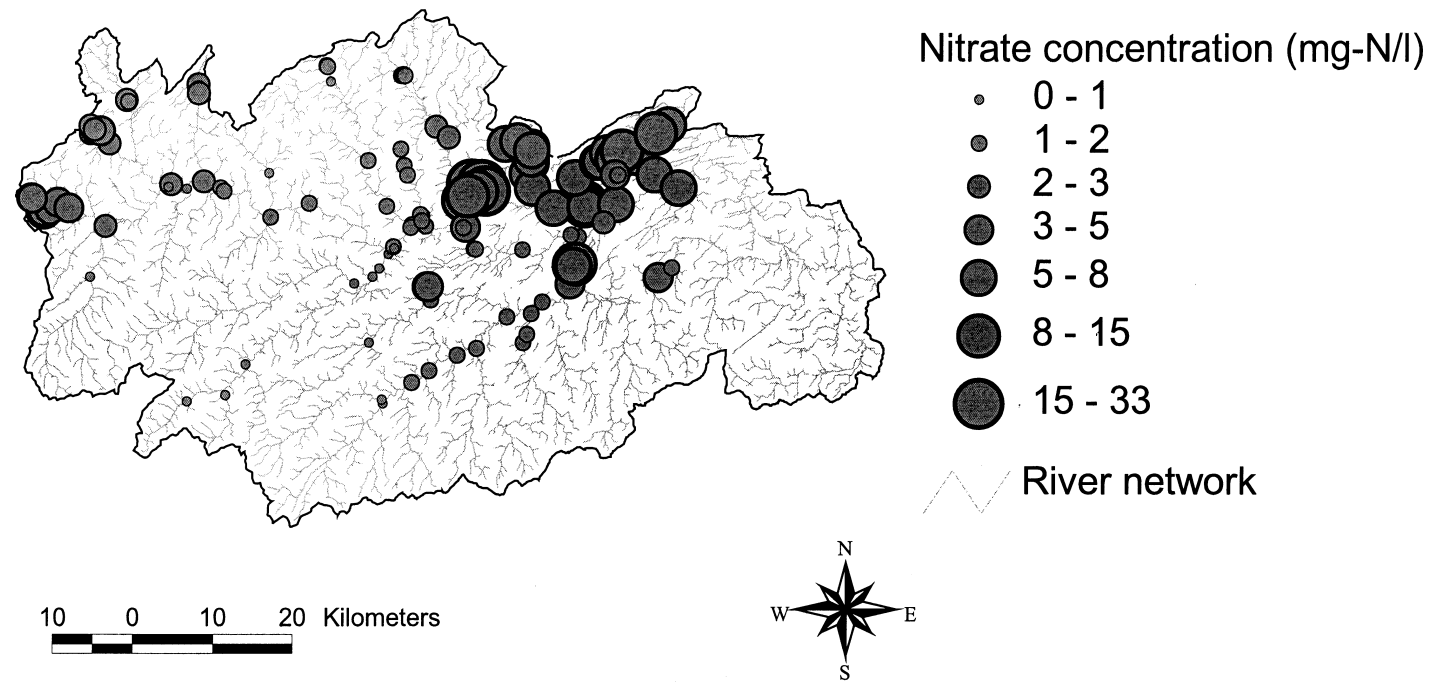

River network

Fig. 1. Map of average nitrate concentrations across the Tweed catchment (1994 to 2000). Data supplied by the Scottish Environment Protection Agency. 
Table 2. Reach structure used for INCA modelling of the River Tweed and data on Base Flow Index and effluent inputs

\begin{tabular}{|c|c|c|c|c|c|c|}
\hline $\begin{array}{l}\text { Reach } \\
\text { No. }\end{array}$ & Reach Name & Length (m) & $\begin{array}{l}\text { Base Flow } \\
\text { Index* }\end{array}$ & $\begin{array}{l}\text { Effluent } \mathrm{NO}_{3}-\mathrm{N} \\
\text { concentration } \\
\left(m g-N l^{-1}\right)\end{array}$ & $\begin{array}{l}\text { Effluent } \mathrm{NH}_{4}-\mathrm{N} \\
\text { concentration } \\
(\mathrm{mg}-\mathrm{N} / \mathrm{l})\end{array}$ & $\begin{array}{l}\text { Effluent } \\
\text { discharge } \\
\left(m^{3} s^{-1}\right)\end{array}$ \\
\hline 1 & Source & 7000 & 0.45 & 0 & 0 & 0 \\
\hline 2 & Fruid & 7000 & 0.45 & 0 & 0 & 0 \\
\hline 3 & Kingledores & 7000 & 0.5 & 0 & 0 & 0 \\
\hline 4 & Drummelzier & 7500 & 0.5 & 0 & 0 & 0 \\
\hline 5 & Stobo & 6000 & 0.5 & 0 & 0 & 0 \\
\hline 6 & Lyneford & 4500 & 0.56 & 0 & 0 & 0 \\
\hline 7 & Scots' Mill & 8750 & 0.55 & 4.4 & 5.5 & 0.008 \\
\hline 8 & Traquair & 8500 & 0.52 & 0 & 0 & 0 \\
\hline 9 & Juniper & 6000 & 0.52 & 9.7 & 2.3 & 0.01 \\
\hline 10 & Peel & 6500 & 0.52 & 0 & 0 & 0 \\
\hline 11 & Old Tweed Bridge & 7000 & 0.52 & 0 & 0 & 0 \\
\hline 12 & Boleside & 1500 & 0.51 & 5.1 & 2.4 & 0.095 \\
\hline 13 & Galafoot & 2500 & 0.52 & 0 & 0 & 0 \\
\hline 14 & Lowood & 2500 & 0.52 & 9.2 & 5.3 & 0.1 \\
\hline 15 & Leaderfoot & 6500 & 0.52 & 8.6 & 3.8 & 0.01 \\
\hline 16 & Mertoun & 8500 & 0.52 & 4.4 & 19.2 & 0.004 \\
\hline 17 & Rutherford & 7000 & 0.52 & 15.3 & 13.1 & 0.004 \\
\hline 18 & Upper Floors & 7500 & 0.52 & 0 & 0 & 0 \\
\hline 19 & Sprouston & 6500 & 0.52 & 1 & 21.4 & 0.025 \\
\hline 20 & Homebank & 8000 & 0.52 & 0 & 0 & 0 \\
\hline 21 & Coldstream & 8000 & 0.52 & 0 & 0 & 0 \\
\hline 22 & St Cuthberts & 4000 & 0.52 & 1.5 & 18.3 & 0.004 \\
\hline 23 & Norham & 6000 & 0.52 & 0 & 0 & 0 \\
\hline
\end{tabular}

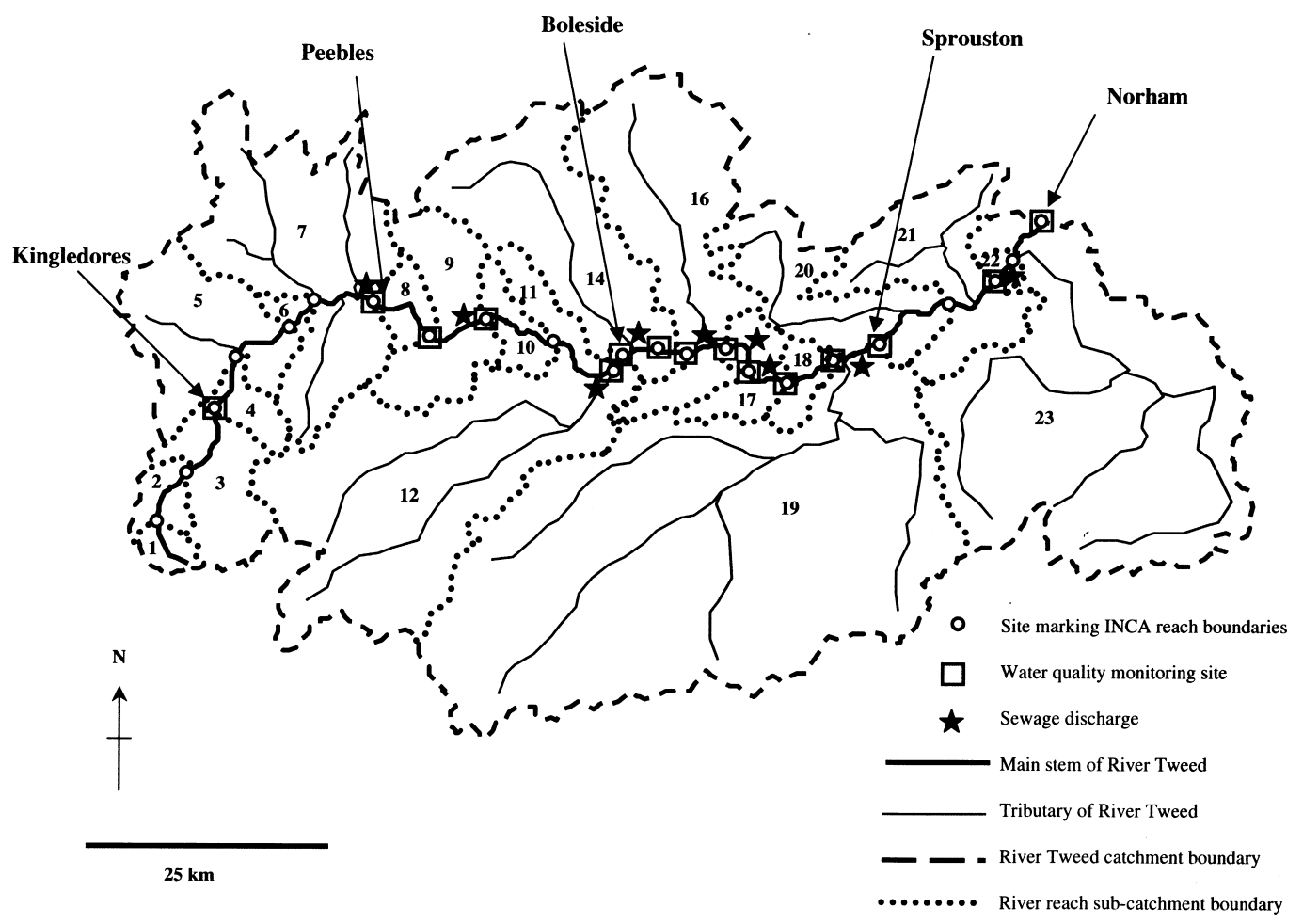

Fig. 2. Map of the Tweed catchment showing INCA reach boundaries, the sub-catchment area draining to each reach and the location of water quality monitoring sites, sewage treatment works and river flow gauging stations (labelled with arrows). 


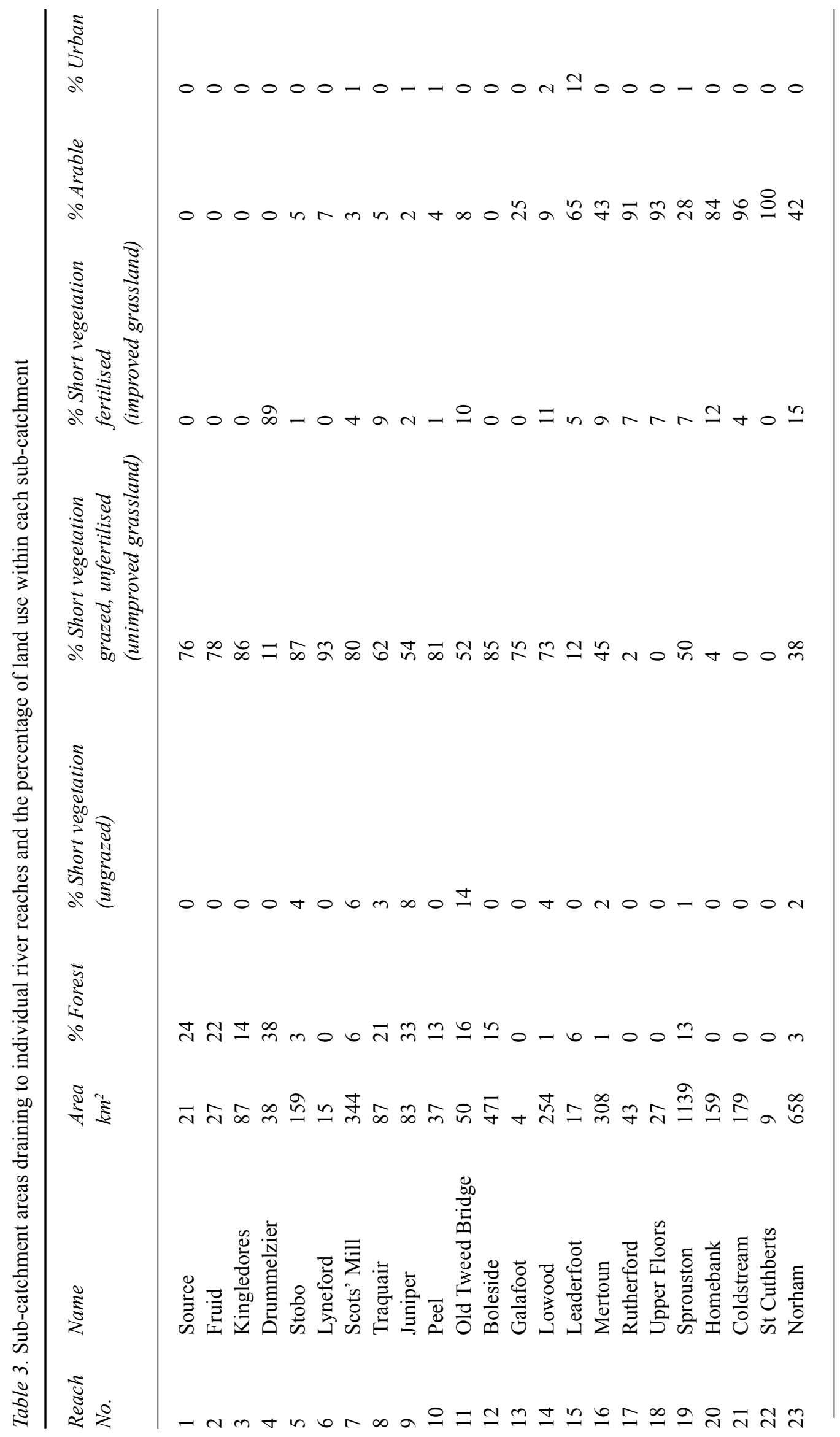




\section{WATER CHEMISTRY DATA}

LOIS water quality sampling took place on a weekly basis at three sites on the main River Tweed from 1994 to 1996. Two of the LOIS sampling sites were located on the main stem of the Tweed and are used here (Boleside (Reach 12) and Norham (Reach 23)). SEPA sampling provides a good spatial distribution across the catchment, with river water samples collected typically on a monthly basis, except for the Tweed at Galafoot (Reach 13) where samples are collected on a weekly basis. SEPA also collects effluent chemistry and flow data, which provide another important input to the INCA model. For the LOIS programme, $\mathrm{NO}_{3}-\mathrm{N}$ concentrations were analysed using ion chromatography (Dionex DX1000 system) and $\mathrm{NH}_{4}-\mathrm{N}$ concentrations were determined by automated colorimetry (Leeks et al., 1997). For the SEPA water quality monitoring programme, both $\mathrm{NO}_{3}-\mathrm{N}$ and $\mathrm{NH}_{4}-\mathrm{N}$ concentrations were determined by ion chromatography. The LOIS chemical monitoring programme was subject to strict harmonisation and quality control measures (Leeks et al., 1997), and similarly, the SEPA analytical laboratories operate under UKAS accredited procedures. This meant that there was good agreement between the SEPA and LOIS datasets so that they could be collated and merged on the LOIS rivers database (Tindall and Moore, 1997). This provided a dataset for the Tweed catchment spanning seven years (1994 to 2000 , inclusive), for a wide range of river and effluent monitoring sites. Of the SEPA river water quality monitoring sites across the Tweed catchment, twelve sites were located along the main stem of the Tweed. These twelve SEPA sites, in addition to the two LOIS water quality monitoring sites mentioned above (Fig. 2), provided the nitrate concentration data for INCA. Additionally, nine sewage treatment works discharged directly into the River Tweed between the source and Norham (Table 2).

\section{DEPOSITION CHEMISTRY}

Nitrogen inputs from atmospheric deposition were estimated using the MATADOR-N model (Model of Atmospheric Transport And Deposition Of Reacting Nitrogen, Rodgers, 1993; RGAR, 1997). This model provides an estimate of long-range transport and wet and dry deposition of oxidised and reduced $\mathrm{N}\left(\mathrm{NO}_{\mathrm{x}}\right.$ and $\left.\mathrm{NH}_{\mathrm{y}}\right)$. Details of calculation methods are provided elsewhere (Whitehead et al., 1998a; Wade et al., 2001). Using MATADOR-N, the mean annual wet and dry deposition over the Tweed catchment was estimated as $3 \mathrm{~kg} \mathrm{ha}^{-1} \mathrm{yr}^{-1}$ for both $\mathrm{NO}_{3}-\mathrm{N}$ and $\mathrm{NH}_{4}-\mathrm{N}$, based on 1994 meteorological and emission data.

\section{HYDROLOGICAL DATA}

Five flow gauging stations on the main stem of the River Tweed (Fig. 2), supplied observed mean daily river flows. Hydrological input data are required to drive the hydrological component of the INCA model; these inputs are daily timeseries of hydrologically effective rainfall (HER, rainfall which penetrates the ground after allowing for evapotranspiration and interception losses), soil moisture deficit and air temperature (Fig. 3). The hydrological input data demonstrate a high degree of variability in the hydrological conditions experienced over the seven year study period. There were relatively low rainfall inputs and high summer soil moisture deficits during 1994 to 1996,
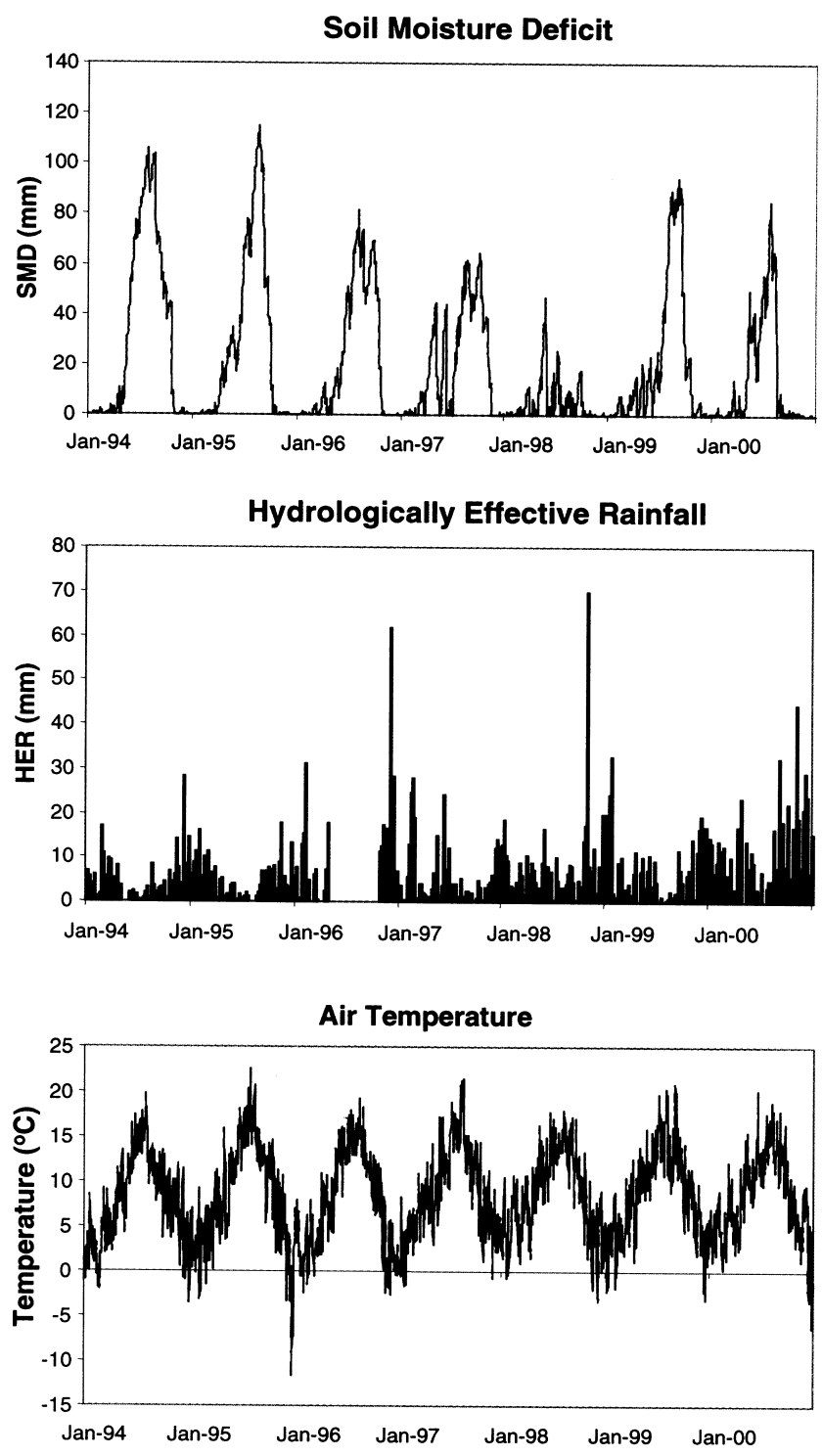

Fig. 3. MORECS data for the Tweed catchment: hydrological timeseries input for INCA (Soil Moisture Deficit (SMD), Hydrologically Effective Rainfall (HER) and air temperature from 1994 to 2000). 
including a prolonged period with no HER during the summer of 1996, followed by high rainfall and relatively low soil moisture deficits during 1997 and 1998. The hydrological input data were supplied by the UK Meteorological Office, based on meteorological observations and output from the MORECS soil moisture and evaporation accounting model (Meteorological Office, 1981). However, the high degree of spatial variability in rainfall across the Tweed catchment meant that, to calibrate the hydrological component of INCA, separate timeseries of HER were required for the upland and lowland areas of the catchment, rather than a single catchment average. The IHACRES model (Jakeman et al., 1990) was used to simulate the differences in HER in the upper (Reaches 1 to 12) and lower (Reaches 13 to 23) parts of the catchment, using the method described by Wade et al. (2001). IHACRES was calibrated using the MORECS-derived actual precipitation and air temperature data, together with the observed flow data at the flow gauging stations at Boleside (Reach 12) and Norham (Reach 23). IHACRES was calibrated using hydrological data from 1994 to 1997 and tested using the data from 1998 to 2000.

Velocity-flow information is required to estimate residence times of water within each river reach, and has been derived from tracer experiments conducted by SEPA. These data have been used to define the following flow-velocity relationship:

$$
\mathrm{V}=\mathrm{a} \mathrm{Q}^{\mathrm{b}}
$$

where $\mathrm{V}$ and $\mathrm{Q}$ are mean daily velocity and flow respectively; $\mathrm{a}$ and $\mathrm{b}$ are constants; for the Tweed, $\mathrm{a}=0.02$ and $b=0.67$.

In INCA, the baseflow index (Gustard et al., 1987) is used to partition the water moving between the soilwater and ground water reservoirs (see Wade et al., 2002). The baseflow index is a measure of the proportion of river runoff which is derived from stored sources and, for the River Tweed, the baseflow index ranges from 0.45 to 0.56 (Institute of Hydrology, 1998).

\section{CATCHMENT LAND USE}

Sub-catchment areas draining to each of the 23 river reaches were defined using the Institute of Hydrology Digital Terrain Model (IHDTM) within a Geographical Information System (GIS; ARC/INFO). Within each of the subcatchment areas, the land use characteristics were derived from the ITE Land Cover data (Fuller, 1993). The twenty five ITE land cover classes were then grouped into six categories, as defined by Whitehead et al. (1998a) : (i) forest, (ii) short vegetation ungrazed, (iii) short vegetation grazed not fertilised (unimproved grassland), (iv) short vegetation grazed and fertilised (improved grassland), (v) arable, (vi) urban. Details of the sub-catchment areas draining to each of the Tweed river reaches and percentage cover of each land use type within each sub-catchment are shown in Table 3.

\section{LAND MANAGEMENT AND PLANT/CROP GROWTH} PERIODS

Typical fertiliser application rates to arable and improved grassland were obtained from the British Survey of Fertiliser Practice (Fertiliser Manufacturers' Association, 1994), and estimated as $41 \mathrm{~kg}^{-\mathrm{N} \mathrm{ha}}{ }^{-1} \mathrm{yr}^{-1}$ for both $\mathrm{NO}_{3}-\mathrm{N}$ and $\mathrm{NH}_{4}-\mathrm{N}$ applications to improved grassland and $53 \mathrm{~kg}-\mathrm{N} \mathrm{ha}^{-1} \mathrm{yr}^{-1}$ $\mathrm{NO}_{3}-\mathrm{N}$ and $\mathrm{NH}_{4}-\mathrm{N}$ applications to arable land. The timings of applications were estimated to run between 1st March and 1st September, based on local farming knowledge (see Appendix). It was assumed that fertiliser input occurred evenly over the period of application and was predominantly applied in the form of ammonium nitrate. The main plant growing season was estimated to begin on 1st March and end on 31st October, with the exception of arable land, where the growing season was estimated to end at harvest time (7th September).

\section{Model calibration}

The availability of seven years of flow and $\mathrm{NO}_{3}-\mathrm{N}$ concentrations for the River Tweed meant that a split sample test could be undertaken, with calibration of the model during the first four years (1994 to 1997, inclusive), and model testing during the final three years (1998 to 2000). Model calibration was undertaken in three steps:

1. Hydrology. Simulation of nitrogen concentrations and loads in both catchment and stream components is dependent on water volumes and the routing of water through the soil, groundwater and river reaches. Therefore, it is important to simulate hydrology accurately. Parameters relating to the flow-velocity relationship were set according to experimental tracer observations. Constants defining the residence times of water in the soil and groundwater reservoirs were determined through calibration, until the simulated mean daily flows closely matched the observed mean daily flows for the 1994-1997 period (Fig. 4).

2. Initial conditions. Having set the fertiliser applications and plant growth periods according to local land management practices, the second step in the calibration 
(a) Reach 12 (Boleside)

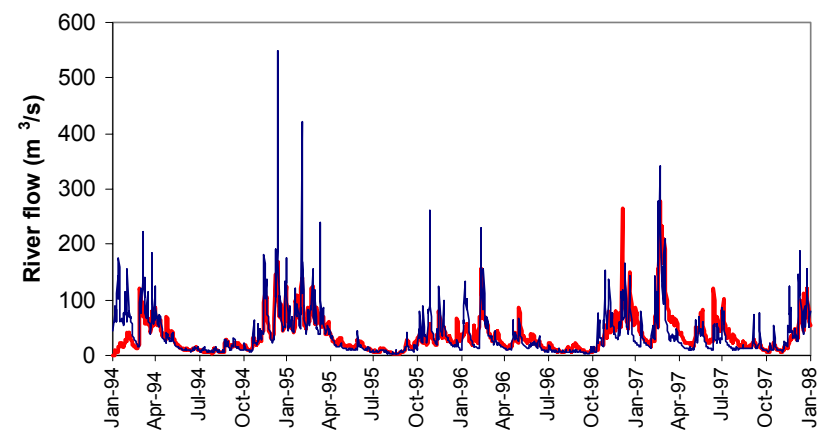

(b) Reach 23 (Norham)

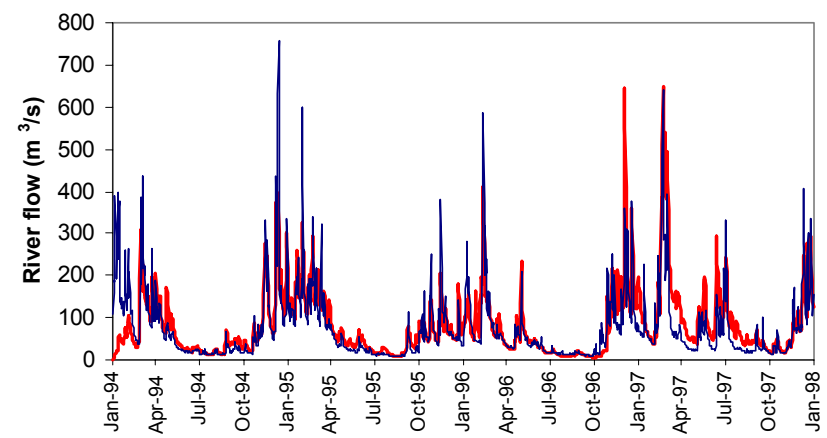

Fig. 4. INCA calibration results for hydrology: observed and simulated river flows at Boleside (Reach 12) and Norham (Reach 23) for 1994 to 1997. Observed flows are shown in dark blue; simulated flows are shown in

procedure involved adjusting initial $\mathrm{NO}_{3}-\mathrm{N}$ and $\mathrm{NH}_{4}-\mathrm{N}$ concentrations in the soil, groundwater and instream components, so that that the simulated flow and initial $\mathrm{NO}_{3}-\mathrm{N}$ concentrations in the first few days of the model run matched observed in-stream concentrations. River water $\mathrm{NH}_{4}-\mathrm{N}$ and $\mathrm{NO}_{2}-\mathrm{N}$ concentrations in the River Tweed were typically close to or below analytical detection limits, and therefore the INCA model of the Tweed was not calibrated to observed $\mathrm{NH}_{4}-\mathrm{N}$ and $\mathrm{NO}_{2}-\mathrm{N}$ data. By running the model to simulate a fouryear period with a daily time step, the influence of initial conditions on model results was minimised.

3. Process rates. Parameters relating to soil nitrogen processes (rates of $\mathrm{NH}_{4}-\mathrm{N}$ immobilisation, $\mathrm{NO}_{3}-\mathrm{N}$ denitrification, $\mathrm{NH}_{4}-\mathrm{N}$ nitrification, $\mathrm{NH}_{4}-\mathrm{N}$ mineralisation, and plant $\mathrm{NH}_{4}-\mathrm{N}$ and $\mathrm{NO}_{3}-\mathrm{N}$ uptake) and instream rates of denitrification and $\mathrm{NH}_{4}-\mathrm{N}$ nitrification were adjusted so that (i) the simulated annual fluxes for catchment processes and annual leaching loads were largely within expected ranges of published data for relevant land use types (see Table 4), and (ii) the simulated daily $\mathrm{NO}_{3}-\mathrm{N}$ concentrations matched observed daily $\mathrm{NO}_{3}-\mathrm{N}$ values closely during $1994-1997$ (Fig. 5). The calibrated parameter values are shown in the Appendix. While these values cannot be compared directly with measured parameters (they have no direct physical process meaning), they serve as a basis for comparison with other INCA applications. Moreover, the loads derived for each process can be compared with measurements made in the field and provide a further means of calibrating the model in addition to matching the observed flows and streamwater nitrate and ammonium concentrations.

Table 4. Catchment process loads: comparing measured

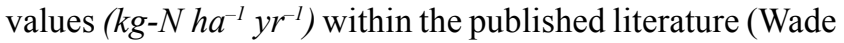
et al., 2001a) with simulated mean annual fluxes $(\mathrm{kg}-\mathrm{N}$ $h a^{-1} y r^{-1}$ ) during 1994 to 1997 in the Tweed catchment

\begin{tabular}{lll}
\hline Land use/Process & $\begin{array}{l}\text { Measured value } \\
\text { or range in } \\
\text { values }\end{array}$ & $\begin{array}{l}\text { Simulated } \\
\text { value for } \\
\text { Tweed }\end{array}$ \\
\hline
\end{tabular}

(1) $\mathrm{NO}_{3}-\mathrm{N}$ uptake

Forest

$17-153$

16

Ungrazed short vegetation

42

19

Unimproved grassland

$35-162$

19

Improved grassland

105

71

Arable

95

94

\section{(2)Denitrification}

Forest

$<0.01-4 \quad 0.5$

Ungrazed short vegetation

Unimproved grassland

Improved grassland

1

1

0.7

2

16

\section{(3) Nitrification}

Forest

Ungrazed short vegetation

$1-35$

12

$3-54$

17

(4) Mineralisation

Forest

$10-292$

41

Ungrazed short vegetation

$20-60$

41

Unimproved grassland

73

$40-50$

52

Improved grassland

Arable

62

(5) Inorganic $N$ leaching

Forest

$<1-43$

6 
(a) Reach 9 (Juniper)

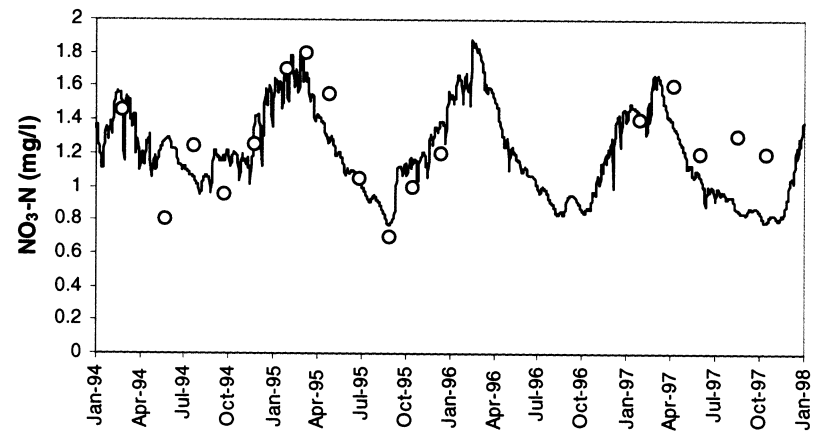

(b) Reach 13 (Galafoot)

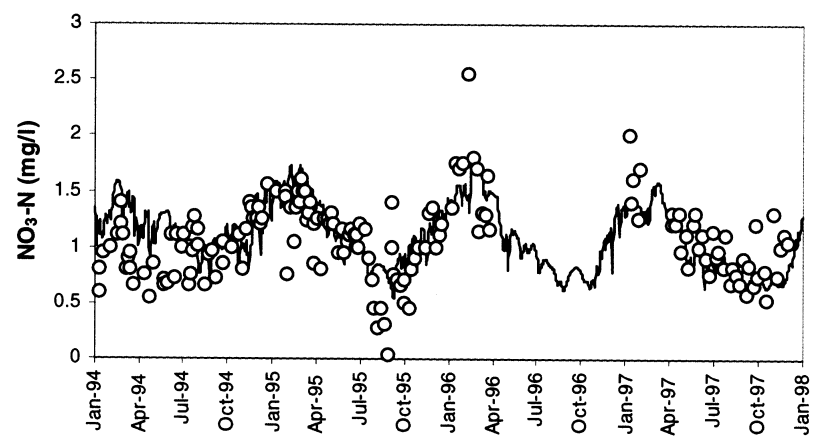

(c) Reach 23 (Norham)

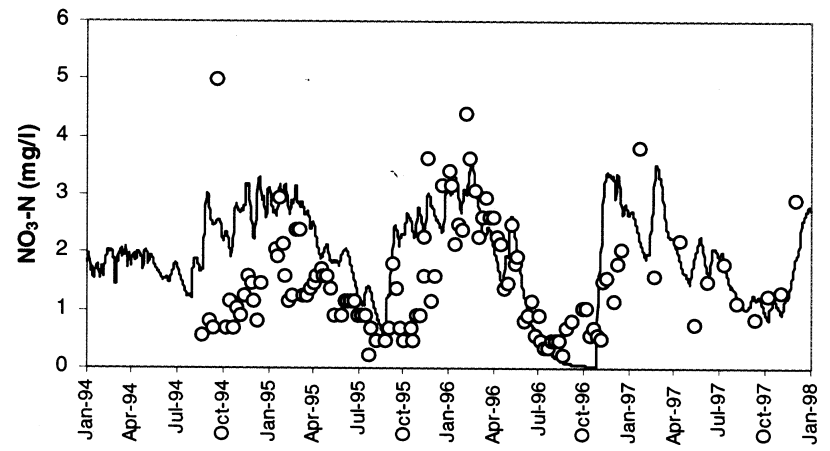

Fig. 5. INCA calibration results for nitrate: observed and simulated $\mathrm{NO}_{3}-\mathrm{N}$ concentrations at Juniper (Reach 9), Galafoot (Reach 13) and Norham (Reach 23) for 1994 to 1997. Observed nitrate concentrations are shown as open circles; simulated nitrate concentrations are shown as a solid black line.

\section{COMPARING OBSERVED AND SIMULATED STREAMFLOW HYDROGRAPHS}

Observed mean daily river flows at Boleside and Norham gauging stations from 1994 to 1997 and the corresponding simulated mean daily river flows, following calibration of the INCA model, are shown in Fig. 4. The INCA hydrological calibration reproduces the dynamics of flow in the Tweed, although it tends to underestimate peak flows, especially at the upper site, Boleside. The fit of the calibrated
Table 5. Co-efficients of determination when comparing observed and simulated river flows for the model calibration phase (1994-1997) and model testing (1998 to 2000). (Coefficients of determination were calculated using the methods of Nash and Sutcliffe, 1970).

\begin{tabular}{lll}
\hline Reach No. & $\begin{array}{l}1994 \text { to } 1997 \\
\text { (model calibration) }\end{array}$ & $\begin{array}{l}1998 \text { to } 2000 \\
\text { (model testing) }\end{array}$
\end{tabular}

\begin{tabular}{lll}
\hline 3 Kingledores & $<0$ & $<0$ \\
6 Lyneford & $<0$ & 0.21 \\
7 Scots Mill & 0.36 & 0.51 \\
12 Boleside & 0.54 & 0.59 \\
19 Sprouston & 0.47 & 0.61 \\
21 Norham & 0.56 & 0.56 \\
\hline
\end{tabular}

model simulations to the observed flow data (1994 to 1997) was assessed quantitatively by calculating the coefficient of determination (CoefOD) for each of the flow gauging sites along the River Tweed (Table 5), where the CoefOD is defined as follows (Nash and Sutcliffe, 1970):

$$
\text { CoefOD }=1-\left(\Sigma\left(\mathrm{O}_{\mathrm{i}}-\mathrm{P}_{\mathrm{i}}\right)^{2} / \Sigma\left(\mathrm{O}_{\mathrm{i}}-\mu_{\mathrm{o}}\right)^{2}\right)
$$

For the ith value of data from 1 to $\mathrm{n}, \mathrm{O}$ is the observed value, $\mathrm{P}$ is the predicted value and $\mu_{\mathrm{o}}$ is the mean of the observed values $\left(\sum_{\mathrm{i}=1} \mathrm{O}_{\mathrm{i}} / \mathrm{n}\right)$

The coefficients of determination for flow in Reaches 12 to 21 are all approximately 0.5 and above, therefore indicating a successful model fit for the lower river reaches. However, at the two upper gauging stations, the coefficients of determination were less than zero. This is likely to result from reservoir storage and abstractions, which can have significant effects on the river flow at Kingledores, Lyneford and Scots Mill, but which have only a minor effect downstream of Boleside (Institute of Hydrology 1998).

\section{COMPARING OBSERVED AND SIMULATED NITRATE CONCENTRATIONS}

Examples of observed and simulated $\mathrm{NO}_{3}-\mathrm{N}$ concentrations are shown in Fig. 5 for sites in the upper catchment (Juniper, Reach 9), middle catchment (Galafoot, Reach 13) and lower catchment (Norham, Reach 23), and the coefficients of determination (CoefOD) for $\mathrm{NO}_{3}-\mathrm{N}$ at the water quality sampling sites along the River Tweed during the 1994 to 1997 calibration period are shown in Table 6. Figure 5 shows that dynamics of $\mathrm{NO}_{3}-\mathrm{N}$ variability are represented adequately by model simulations, especially in the middle 
Table 6. Co-efficients of determination when comparing observed and simulated nitrate concentrations for the model calibration phase (1994-1997) and model testing (1998 to 2000). (Co-efficients of determination were calculated using the methods of Nash and Sutcliffe, 1970).

\begin{tabular}{llcl}
\hline $\begin{array}{l}\text { Reach } \\
\text { No. }\end{array}$ & Name & $\begin{array}{l}\text { 1994 to 1997 } \\
\text { (model } \\
\text { calibration) }\end{array}$ & $\begin{array}{l}\text { 1998 to 2000 } \\
\text { (model } \\
\text { testing) }\end{array}$ \\
\hline 3 & Kingledores & $<0$ & $<0$ \\
9 & Juniper & 0.35 & 0.19 \\
11 & Old Tweed Bridge & 0.44 & 0.25 \\
12 & Boleside & 0.08 & $\mathrm{~N} / \mathrm{D}$ \\
13 & Galafoot & 0.26 & 0.25 \\
14 & Lowood & $<0$ & 0.4 \\
15 & Leaderfoot & $<0$ & 0.36 \\
17 & Rutherford & 0.28 & 0.18 \\
18 & Upper Floors & $<0$ & $<0$ \\
21 & Coldstream & 0.19 & 0.14 \\
23 & Norham & $<0$ & 0.13 \\
\hline
\end{tabular}

and upper catchment, and this is reflected in the CoefOD, which reach values of 0.35 at Juniper and 0.26 at Galafoot. However, at Norham, the coefficient of determination is less than zero for the calibration period. The main problem seems to be an over-estimation of $\mathrm{NO}_{3}-\mathrm{N}$ concentrations during the low-flow period from July to November 1994, and the subsequent period of wetting up and catchment nitrate delivery during the winter of 1994/1995. This may reflect the inability of INCA to model in-stream uptake of nitrogen by aquatic plants, which are an important feature of the tributaries in the lower agricultural parts of the basin. Indeed, the lower reaches of the main river channel are subject to prolific growth of aquatic plants under extreme summer baseflow conditions. The summer of 1995 was particularly dry, hot and sunny, with prolific filamentous algal growth recorded from Ettrick Foot (Reach 14) to the tidal limit (Tweed River Purification Board, 1996).

The CoefOD across the water quality monitoring sites (Table 6) show a wide variation in the success of the model fit during the 1994 to 1997 calibration phase, ranging from CoefODs of less than zero in Reaches 3, 14, 15, 18 and 23, to a CoefOD of 0.44 in Reach 11 (Old Tweed Bridge). The absence of any obvious patterns in CoefOD values along the river demonstrates that there is a high degree of local variation in the processes controlling nitrogen leaching and transport in the different catchment vegetation/soil systems and within individual river reaches.

Both observed and simulated $\mathrm{NO}_{3}-\mathrm{N}$ concentrations demonstrate well-defined seasonality (Fig. 5), with lowest concentrations occurring during the summer and rising $\mathrm{NO}_{3}-\mathrm{N}$ concentration in the autumn and winter, as soils wet up and nitrogen is flushed from the catchment. Typically, peak $\mathrm{NO}_{3}-\mathrm{N}$ concentrations occur in late February/early March. The low summer concentrations reflect (a) lower flows and thus reduced delivery of diffuse-source nitrogen from the catchment, and (b) higher water residence times within the river reaches, promoting greater in-stream denitrification.

\section{Model testing}

The parameters derived by calibrating INCA for the River Tweed between 1994 and 1997 were then used with data collected between 1998 and to assess whether simulations would reproduce spatial variations in average flow and $\mathrm{NO}_{3}$ $\mathrm{N}$ along the river reaches. Hydrological and $\mathrm{NO}_{3}-\mathrm{N}$ dynamics were then tested by comparing simulated mean daily flows and $\mathrm{NO}_{3}-\mathrm{N}$ concentrations for 1998 to 2000, with corresponding observed flows and $\mathrm{NO}_{3}-\mathrm{N}$ concentrations using the model parameters derived from the calibration run.

\section{SPATIAL VARIATIONS IN FLOW AND NITRATE CONCENTRATIONS}

The simulated mean annual flow values and $\mathrm{NO}_{3}-\mathrm{N}$ concentrations (calculated from the 1998 to 2000 data) along the 23 reaches of the River Tweed compare well with observed mean annual values (Figs. 6 and 7). For $\mathrm{NO}_{3}-\mathrm{N}$, mean annual observed concentrations are based on a restricted number of water quality samples, whereas the simulated mean annual $\mathrm{NO}_{3}-\mathrm{N}$ concentrations are based on daily simulated values. Therefore, to calculate a CoefOD to

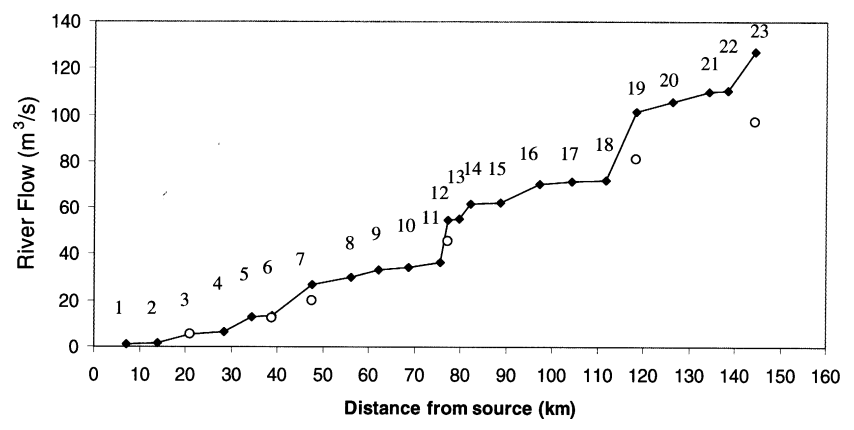

Fig. 6. Spatial variations in simulated and observed mean river flows along the River Tweed during the model test period (19982000). Observed flow values are shown as open circles; simulated flow values are shown as black diamonds, joined by a solid black line. Reach numbers are shown on the graph. 


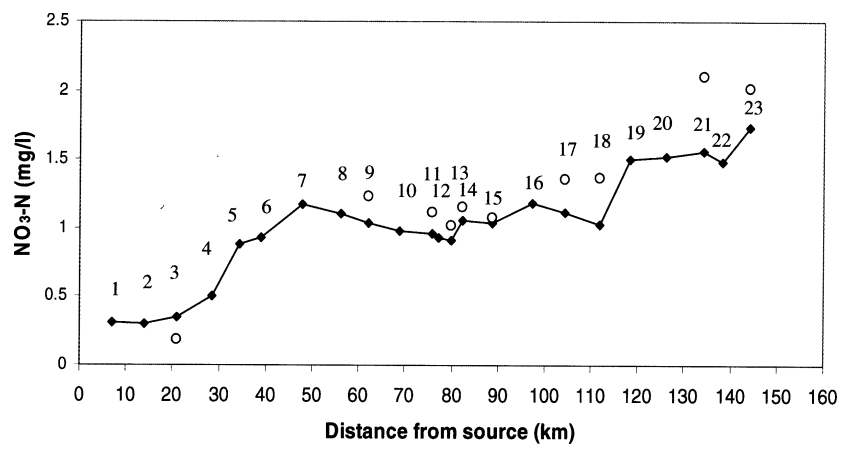

Fig. 7. Spatial variations in simulated and observed mean $\mathrm{NO}_{3}-\mathrm{N}$ concentrations along the River Tweed during the model test period (1998 - 2000). Observed nitrate concentrations are shown as open circles; simulated nitrate concentrations are shown as black diamond joined by a solid black line. Reach numbers are shown on the graph.

compare observed and simulated mean annual $\mathrm{NO}_{3}-\mathrm{N}$ concentrations, the simulated means were calculated using only those values corresponding with the dates when observed $\mathrm{NO}_{3}-\mathrm{N}$ data were available. The CoefOD was 0.80 for flow and 0.78 for $\mathrm{NO}_{3}-\mathrm{N}$, indicating a very good model fit for mean annual spatial variations in both flow and $\mathrm{NO}_{3}$ $\mathrm{N}$ along the River Tweed.

The steepest downstream gradients in mean annual flow values correspond with the major tributary inputs: Reach 12, approximately $77 \mathrm{~km}$ from the source (the Ettrick Water), and Reach 19, approximately $120 \mathrm{~km}$ from the source (River Teviot). The steepest gradients in $\mathrm{NO}_{3}-\mathrm{N}$ concentrations occur in Reach 5, which represents a transition from upland vegetation to arable land use, resulting in relatively high $\mathrm{NO}_{3}-\mathrm{N}$ inputs. This reach also receives a relatively small tributary input from the Biggar Water, a headwater stream, receiving high effluent inputs from Biggar sewage treatment works (STW) (Robson et al., 1996). The slight reductions in mean annual $\mathrm{NO}_{3}-\mathrm{N}$ concentrations from Reaches 7 to 13,16 to 18 and 21 to 22 may reflect hydrological dilution with water of lower $\mathrm{NO}_{3}-\mathrm{N}$ concentration and/or in-stream losses of nitrate by in-stream uptake processes along these river reaches. There is a small but steep increase in $\mathrm{NO}_{3}-\mathrm{N}$ concentrations in Reach 14, which receives tributary input from the Gala Water as well as urban runoff from the town of Galashiels and effluent from Galashiels STW. A major increase in $\mathrm{NO}_{3}-\mathrm{N}$ concentrations occurs in Reach 19, corresponding with input from the largest tributary, the River Teviot, which drains intensive arable land and areas with high livestock densities. A further steep increase in $\mathrm{NO}_{3}-\mathrm{N}$ concentrations occurs in Reach 23, which corresponds with the tributary input from the River Till draining an area of intensive arable land and high livestock densities.

\section{FLOW AND NITRATE DYNAMICS}

Timeseries of daily variations in simulated and observed flow concentration data for the model test period (1998 to 2000) are shown in Fig. 8, for two river reaches: Boleside (Reach 12) and Norham (Reach 23). The model shows a good fit in terms of flow dynamics but, like the 1994 to 1997 calibration period, INCA fails to predict the extreme high flows (some of which may be associated with snowmelt events in winter) and tends, slightly, to overpredict intermediate flows associated with the falling limb of storm hydrographs at both Boleside and Norham. However, CoefODs are relatively high for river flow at both sites for the model test period $(0.59$ and 0.56 at Boleside and Norham respectively, Table 5), demonstrating successful model fit. CoefODs at the upper sites (Kingledores and Lyneford) are significantly lower, with poorer model fit reflecting influence of reservoir storage.

Timeseries of daily simulated and observed $\mathrm{NO}_{3}-\mathrm{N}$ concentrations for 1998 to 2000 are shown in Fig. 9, for three sites: Juniper (Reach 9), Galafoot (Reach 13) and Norham (Reach 23). The model represents the seasonal

(a) Reach 12 (Boleside)

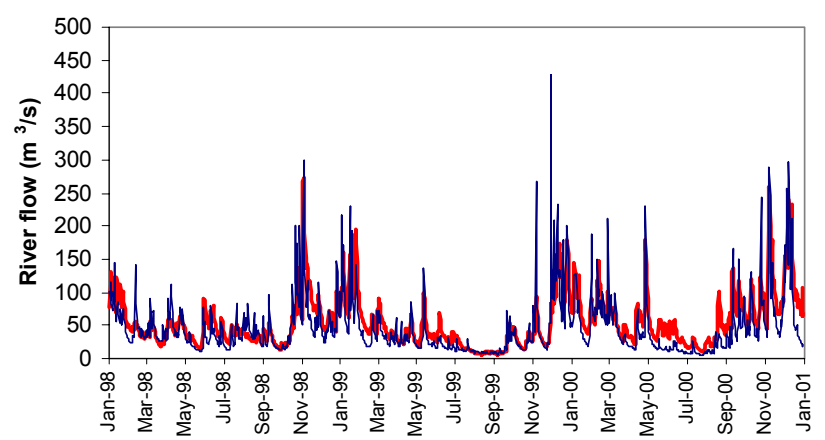

(b) Reach 23 (Norham)

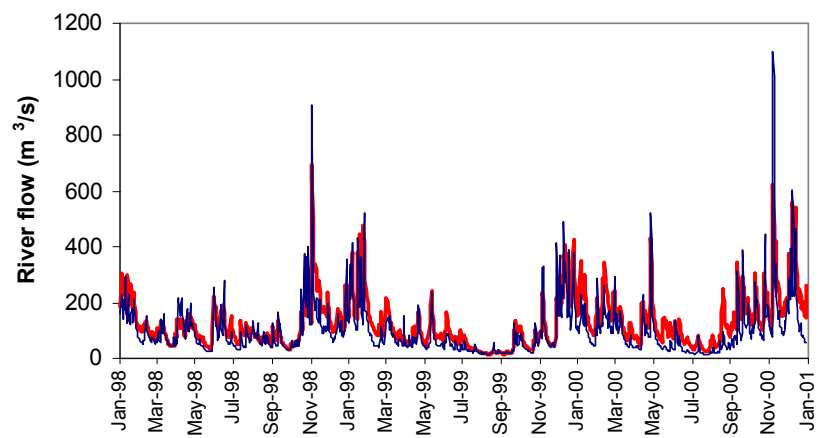

Fig. 8. INCA test results for hydrology: observed and simulated river flows at Boleside (Reach 12) and Norham (Reach 23) for 1998 to 2000. Observed flows are shown in dark blue; simulated flows are shown in red. 
(a) Reach 9 (Juniper)

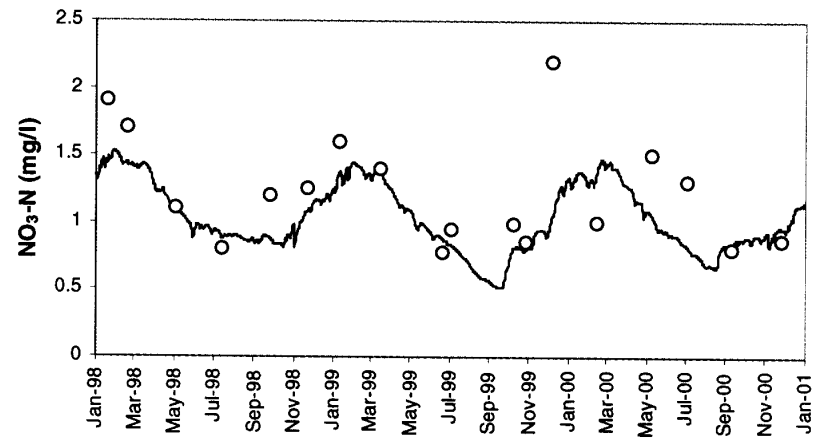

(b) Reach 13 (Galafoot)

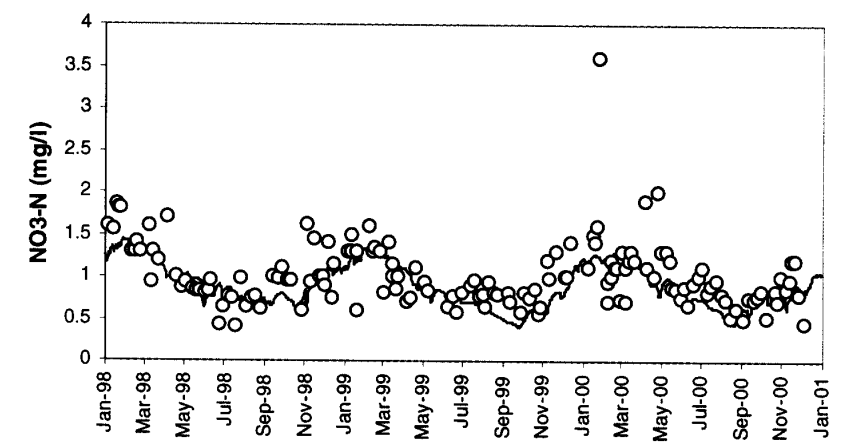

(c) Reach 23 (Norham)

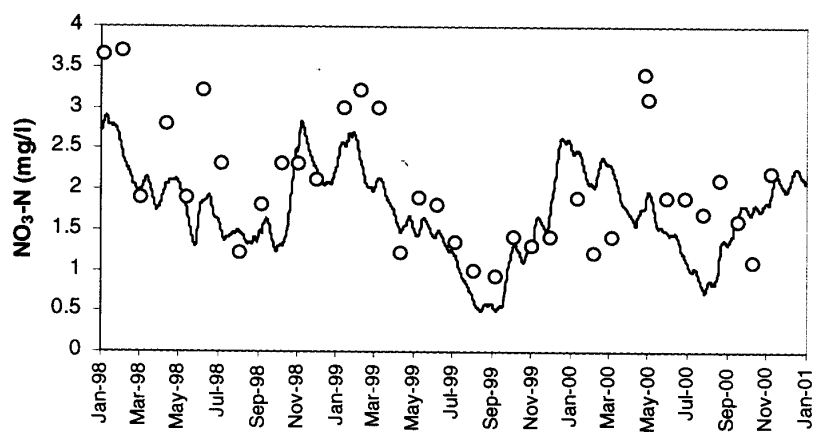

Fig. 9. INCA test results for nitrate: observed and simulated $\mathrm{NO}_{3}-\mathrm{N}$ concentrations at Juniper (Reach 9), Galafoot (Reach 13) and Norham (Reach 23) for 1998 to 2000. Observed nitrate concentrations are shown as open circles; simulated nitrate concentrations are shown as a solid black line.

dynamics in nitrate concentrations at all three sites, with CoefOD values of 0.19 (Juniper), 0.25 (Galafoot) and 0.13 (Norham) (Table 6). Indeed, at Norham, nitrate model fit during 1998 to 2000 is significantly better than during the calibration phase of 1994 to 1997 . During the 1998 to 2000 model test period, INCA tends to underestimate winter peaks in nitrate concentrations, linked to high flow events, especially at Norham. The model test period of 1998 to 2000 was characterised by higher HER than during the calibration phase, especially during the summer months. Higher summer HER has an important control on daily nitrate leaching dynamics, and this produces a better model fit during the summer lower flows at Norham during 1998 to 2000. CoefOD values demonstrate large variation between river reaches and also between model test and calibration periods (Table 6). These results highlight issues of temporal as well as spatial variations in the processes controlling nitrate leaching and transport in neighbouring subcatchments and river reaches.

\section{Using model simulations to assess spatial and temporal variability in nitrate sources and loads}

Following successful calibration and testing of the Tweed INCA model, simulations were used to investigate sources of nitrate loads (both point and diffuse source leaching loads) to the river and their variability through time. Firstly model simulations were used to examine the relative contribution of leaching loads from different land uses and effluent discharge to the annual $\mathrm{NO}_{3}-\mathrm{N}$ load during 1995 along all 23 river reaches. Secondly, seasonal variability in sources was assessed by examining the relative contributions of landuse types and effluents to monthly $\mathrm{NO}_{3}-\mathrm{N}$ loads within Reach 23 (Norham). Thirdly, daily dynamics in $\mathrm{NO}_{3}-\mathrm{N}$ leaching loads were examined for two contrasting land-use types, arable and unfertilised grazing land, which represent the greatest contributors to $\mathrm{NO}_{3}-\mathrm{N}$ leaching loads in the Tweed catchment. The uncertainty in the calibrated parameters means that any simulation results must remain tentative. However, the results are indicative of likely changes in nitrogen dynamics in response to environmental changes.

\section{ATTRIBUTING IN-STREAM NITRATE LOADS ALONG}

\section{THE RIVER TWEED TO DIFFERENT SOURCES}

The simulated relative contributions of nitrate leaching from different land uses to the annual nitrate load of the Tweed from the source to the tidal limit are shown for one example year (1995) in Fig. 10. The urban areas and point source contributions are grouped into one category as the greatest contributions from point sources tend to be found in urban areas, and both sources provide only a very small contribution to total nitrate load in the Tweed catchment. The model simulation results indicate an overwhelming dominance of unimproved grassland to the annual nitrate load in the upper and middle reaches of the Tweed. This reflects the rough livestock grazing within the upper and middle parts of the catchment. Moving downstream towards the lowland river reaches, arable contributions to $\mathrm{NO}_{3}-\mathrm{N}$ 


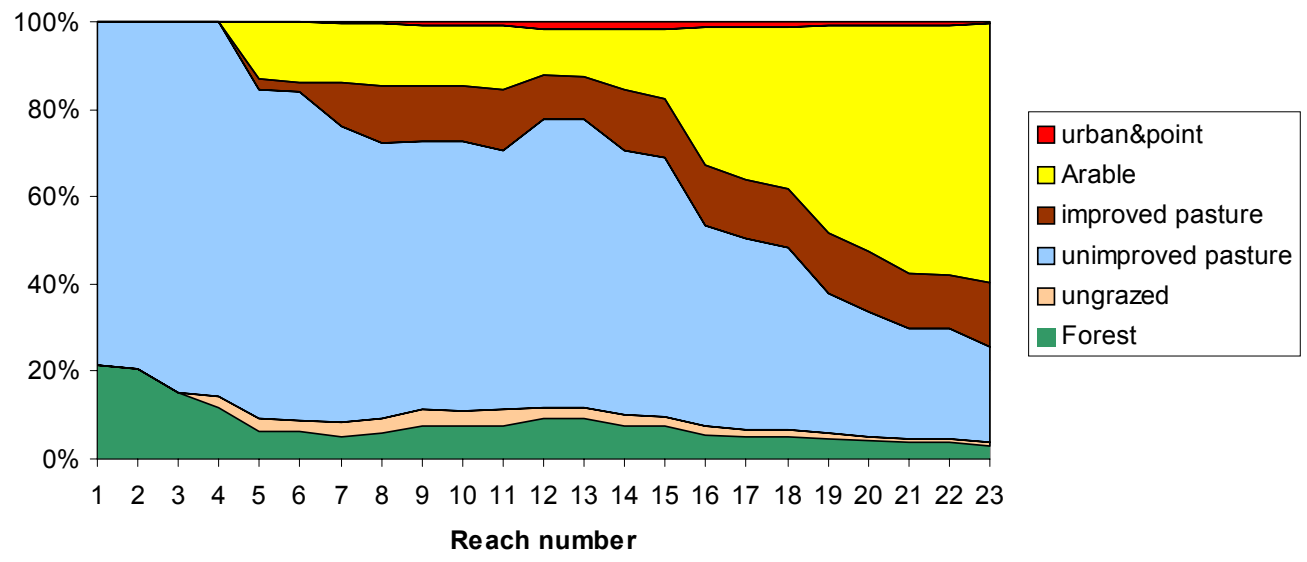

Fig. 10. Simulated relative contributions of different sources to the nitrate load along the River Tweed during 1995.

load increase (as the absolute $\mathrm{NO}_{3}-\mathrm{N}$ loads increase). Below Reach 15 (Leaderfoot), there is a large increase in the proportion of arable-derived $\mathrm{NO}_{3}-\mathrm{N}$, reaching a maximum of approximately $60 \%$ of annual $\mathrm{NO}_{3}-\mathrm{N}$ load at Norham (Reach 23). The Leader tributary which flows into the Tweed in Reach 15 , is a predominantly livestock area, but importantly there is a very large broiler chicken farm in the catchment, and nitrate concentrations in the Turfford Burn tributary have increased rapidly with the expansion of this sector. In the reaches below Lyneford (Reach 6), improved grassland contributes a small but near-constant proportion of $\mathrm{NO}_{3}-\mathrm{N}$ load (around 15\%). Ungrazed land contributes no more than $5 \%$ of total annual load at any point along the river. While forests contribute over $20 \%$ of the annual $\mathrm{NO}_{3}-\mathrm{N}$ load in the upper two reaches, this contribution tails off to under $5 \%$ in the lower reaches of the Tweed. Urban areas and point sources provide the lowest contribution to the annual $\mathrm{NO}_{3}-\mathrm{N}$ load at any point on the river, owing to the rural nature of the catchment and the low human population. Urban and point source inputs are greatest in the middle reaches, reflecting nitrate inputs from the towns of Selkirk, Galashiels, St Boswells and Kelso.

\section{SIMULATED SEASONAL VARIABILITY IN CONTRIBUTING NITRATE SOURCES}

The simulated contributions of the 6 land use categories to the monthly $\mathrm{NO}_{3}-\mathrm{N}$ loads for Juniper (Reach 9), Galafoot (Reach 13) and Norham (Reach 23) are shown in Fig. 11. Throughout 1995, monthly loads of $\mathrm{NO}_{3}-\mathrm{N}$ in the upper and middle reaches (Juniper and Galafoot) were dominated by leaching from unimproved grazing land, accounting for up to approximately $65 \%$ of monthly $\mathrm{NO}_{3}-\mathrm{N}$ loads. In the lower river at Norham, monthly loads of $\mathrm{NO}_{3}-\mathrm{N}$ were dominated by arable leaching which accounted for between

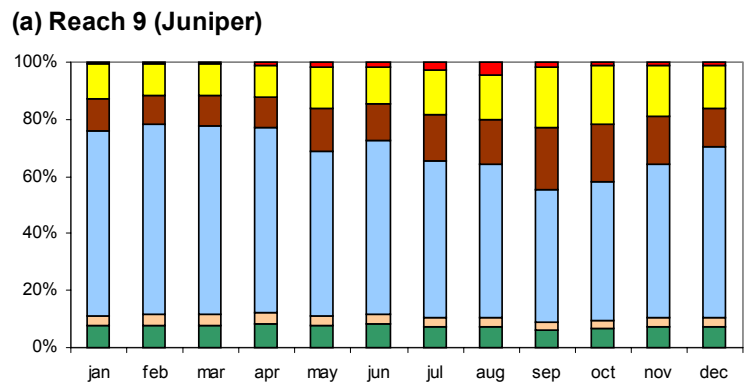

\section{(b) Reach 13 (Galafoot)}

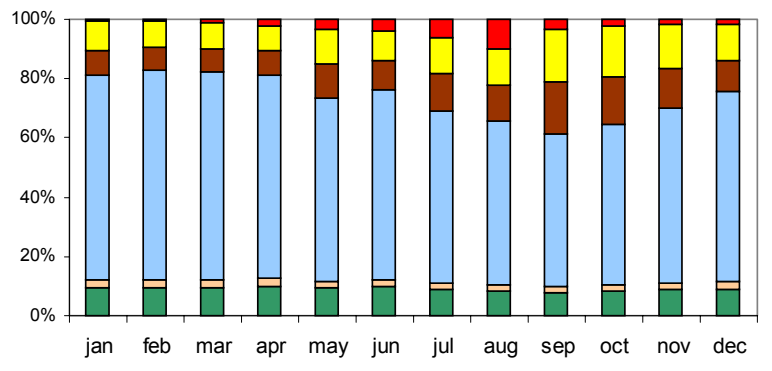

(c) Reach 23 (Norham)

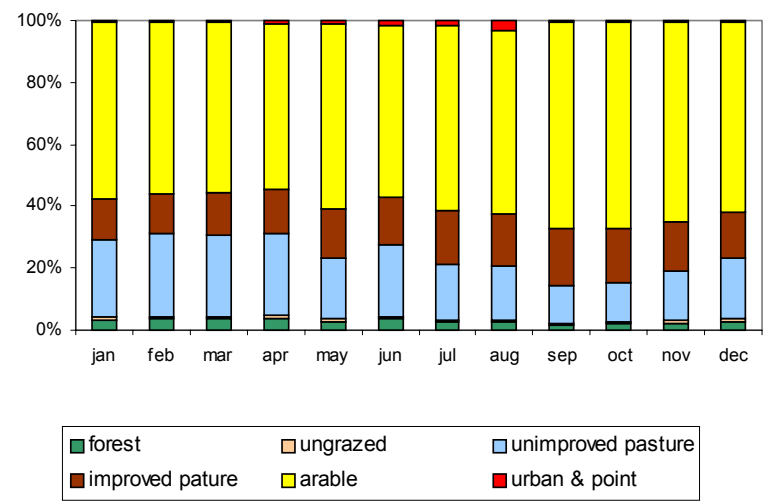

Fig. 11. Simulated relative contributions of different sources to the monthly nitrate load in the River Tweed at Norham (Reach 23) during 1995. 
50 and $70 \%$ of monthly $\mathrm{NO}_{3}-\mathrm{N}$ loads. At all three sites, there is a seasonal pattern in the proportion of urban and point sources; this reaches a maximum in August, reflecting lower river flows and reduced point source dilution during the summer months. Urban areas and point sources provide the greatest contributions to monthly $\mathrm{NO}_{3}-\mathrm{N}$ loads in the mid-catchment at Galafoot (up to $10 \% \mathrm{NO}_{3}-\mathrm{N}$ load in August), reflecting urban and sewage inputs from the town of Galashiels. The percentage of $\mathrm{NO}_{3}-\mathrm{N}$ load from arable and improved grassland increases during the summer at all three sites, whereas unimproved grassland contributes a higher percentage of monthly $\mathrm{NO}_{3}-\mathrm{N}$ loads during the winter. This may reflect greater precipitation inputs and delivery of diffuse source nitrate inputs from the more upland areas during the winter. The proportion of nitrate from forest and ungrazed land remains largely constant throughout the year at all three sites, with a combined contribution of approximately $10 \%$ at Juniper and Galafoot, but only $5 \%$ at Norham.

\section{SIMULATED DYNAMICS IN DAILY NITRATE}

\section{LEACHING LOAD}

Daily nitrate leaching loads, simulated for the subcatchment draining into Reach 13 (Galafoot) are shown in Fig. 12, for the two land-use sources which contribute the largest proportion of nitrate leaching loads within the River Tweed: unimproved grassland and arable. These timeseries demonstrate a high variability in daily simulated $\mathrm{NO}_{3}-\mathrm{N}$ leaching loads for both arable and unimproved grassland, and the timing of peak $\mathrm{NO}_{3}-\mathrm{N}$ inputs resembles the daily HER timeseries closely (Fig. 3). $\mathrm{NO}_{3}-\mathrm{N}$ leaching from both unimproved grassland and arable ceases during the summer/ early autumn period of 1996, because of a lack of hydrologically effective rainfall during this time. Although nitrogen fertilisers are applied to the arable land from the beginning of March to the end of August, this period corresponds with a time of generally lower simulated $\mathrm{NO}_{3}-\mathrm{N}$ leaching loads from arable land. In addition to lower rainfall and thus lower runoff generation, rates of biological activity and uptake of $\mathrm{N}$ are also highest during the summer, resulting in lower $\mathrm{NO}_{3}-\mathrm{N}$ export.

\section{Simulating environmental change within the Tweed catchment and its implications for nitrate leaching and river transport}

The calibrated INCA model of the River Tweed was used to examine the impact of environmental change on nitrate concentrations and loads in the Tweed catchment. Environmental change within the Tweed catchment was modelled in terms of two factors: land use change and changing atmospheric nitrogen deposition.

Five land use scenarios were examined, related to changes in the proportions of different land-use types and fertiliser inputs:

(i) a $20 \%$ reduction in all fertiliser applications;

(ii) all arable land converted to fertilised grassland, receiving no more than $150 \mathrm{~kg}-\mathrm{N} \mathrm{ha}{ }^{-1} \mathrm{yr}^{-1}$;

(iii) all arable land converted to unfertilised ungrazed land;

(iv) all grazed land converted to ungrazed land;

(v) all grazed fertilised land converted to arable; all grazed non-fertilised land converted to ungrazed land; and all existing ungrazed land converted to forestry.

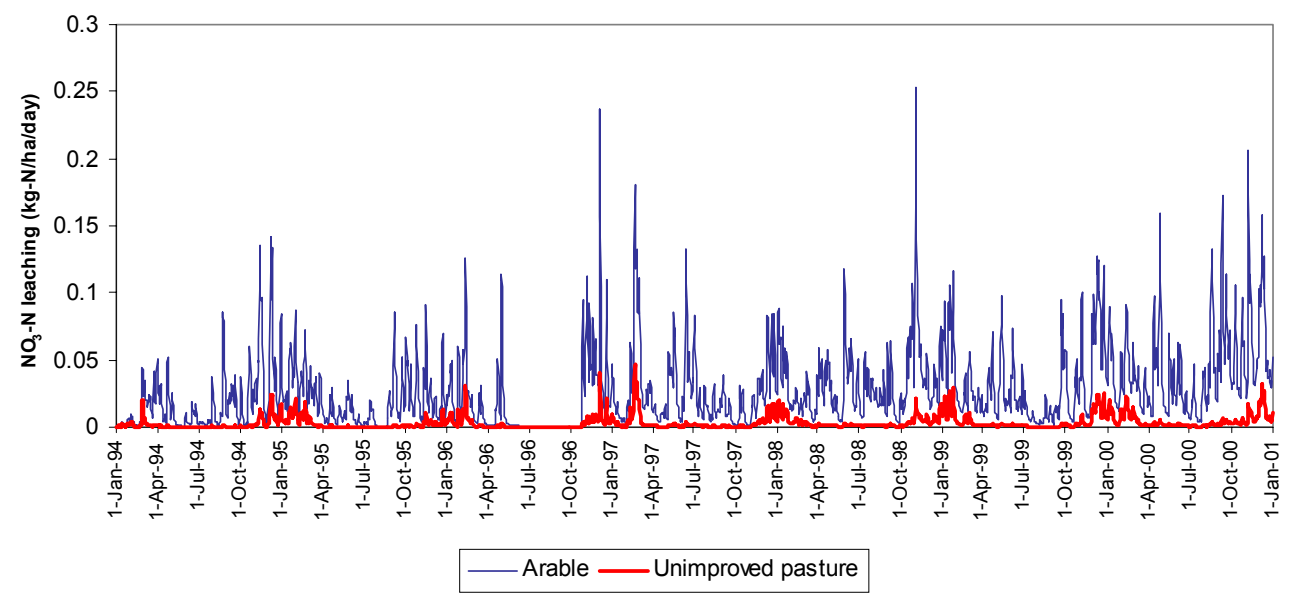

Fig. 12. Simulated daily nitrate leaching loads from unimproved pasture and arable to Reach 13 (Galafoot) 1994 to 2000. 
Scenarios (i) to (iii) correspond with Nitrate Sensitive Areas recommendations (Johnes, 1996; Wade et al., 2001). Scenarios (iv) and (v) are linked to worst-case scenarios of land use change in the Tweed catchment linked to a collapse in livestock farming within the catchment (see the discussion of agricultural change in the earlier description of the Tweed catchment). In scenario (iv), all grassland is converted to ungrazed land. Scenario (v) represents a major reorganisation of land use within the Tweed catchment, with an expansion of arable into the more lowland of the existing livestock areas, an expansion of forestry into existing ungrazed areas, and existing unimproved grazing land being converted to ungrazed land.

Changing atmospheric deposition scenarios were modelled as follows:

$50 \%$ reduction in total $\mathrm{N}$ deposition;

(vii) $50 \%$ increase in total $\mathrm{N}$ deposition;

(viii) $100 \%$ increase in total $\mathrm{N}$ deposition;

(ix) $\quad 200 \%$ increase total $\mathrm{N}$ deposition.

Whilst current European policy encourages reductions in nitrogen emissions, largely though the use of catalytic converters on vehicle exhausts, it is unclear how nitrogen emissions will change in the future. A potentially important factor in changing nitrogen deposition within the Tweed catchment is a move towards more intensive livestock production and poultry farming and resultant increases in atmospheric ammonia emissions from these sources. Therefore, a range of scenarios was considered to cover possible extremes. The INCA Tweed model was run for each of the nine scenarios for the full modelling period (1994 to 2000), by changing the relevant input parameters. The $\mathrm{NO}_{3}-\mathrm{N}$ timeseries output for each scenario was then compared with the output for the calibrated parameter set (the model 'base run'), for two sites characteristic of the upper and lower river reaches (Juniper and Norham). A summary, which compares mean daily $\mathrm{NO}_{3}-\mathrm{N}$ concentrations for the model base run and for each scenario is provided in Table 7. Scenario results are provided in terms of mean daily nitrate concentrations for (a) the full longterm data set (1994 - 2000), (b) summer (June to August), and (c) winter (November to February).

\section{LAND-USE CHANGE SCENARIOS}

Scenarios (i), (ii) and (iii), which are linked to reduced fertiliser inputs and a reduction in the proportion of arable land had the greatest impact on reducing in-stream $\mathrm{NO}_{3}-\mathrm{N}$ concentrations in the lower river reaches, which drain the lowland agricultural parts of the catchment. Scenario (iii) produces the greatest percentage reductions in $\mathrm{NO}_{3}-\mathrm{N}$ concentrations, with $>50 \%$ reduction in the concentration of $\mathrm{NO}_{3}-\mathrm{N}$ at Norham throughout the year. Scenarios (i) and (ii) also result in a greater percentage reduction in $\mathrm{NO}_{3}-\mathrm{N}$ concentrations at Norham during the winter, compared with the summer. This relates to reductions in the availability of fertiliser-derived $\mathrm{N}$ for delivery from the catchment to the river during the main period of nitrate flux transport under high flow conditions during the winter months.

Major agricultural re-organisation, linked to a dramatic reduction of livestock farming within the catchment is modelled in scenarios (iv) and (v). The conversion of all grazing land (both improved and unimproved grassland) to ungrazed land produces an average reduction of approximately $20 \%$ in simulated in-stream mean daily $\mathrm{NO}_{3}-\mathrm{N}$ concentrations in the upper catchment, compared with a $15 \%$ reduction in the lower river reaches. This higher percentage loss in the upper catchment reflects the dominance of grazing land contributions to $\mathrm{NO}_{3}-\mathrm{N}$ leaching loads (approximately $70 \%$ at Reach 9 - Juniper, compared with approximately $35 \%$ at Norham). In scenario (v), the loss of grazing land is buffered to some extent by the conversion of improved grassland to arable land. This results in a much smaller percentage reduction in river $\mathrm{NO}_{3}-\mathrm{N}$ concentrations in the lower catchment (only 1\%), compared with a $6 \%$ reduction in $\mathrm{NO}_{3}-\mathrm{N}$ concentrations in the upper catchment.

\section{ATMOSPHERIC DEPOSITION SCENARIOS}

Scenarios of changing atmospheric total $\mathrm{N}$ inputs all have the greatest impact in the upper catchment compared with the lower catchment. This is because atmospheric nitrogen sources contribute a greater proportion of total $\mathrm{N}$ inputs in the upper catchment, since most upland land uses do not involve intensive application of fertilisers.

Each $50 \%$ change in atmospheric total $\mathrm{N}$ inputs changes long-term mean daily in-stream $\mathrm{NO}_{3}-\mathrm{N}$ concentrations by approximately $3.2 \%$ in the lower catchment, but $4 \%$ in the upper catchment. The percentage change in in-stream $\mathrm{NO}_{3}-\mathrm{N}$ concentrations is greater in winter than in summer. For example, there is a $5 \%$ change in winter mean daily $\mathrm{NO}_{3}-\mathrm{N}$ concentrations per $50 \%$ change in total $\mathrm{N}$ deposition in the upper catchment, compared with a corresponding $3.2 \%$ change in mean daily summer $\mathrm{NO}_{3}-\mathrm{N}$ concentrations. A $200 \%$ increase in total $\mathrm{N}$ deposition is predicted to result in a $21 \%$ increase in winter mean daily $\mathrm{NO}_{3}-\mathrm{N}$ concentrations in the upper catchment. 


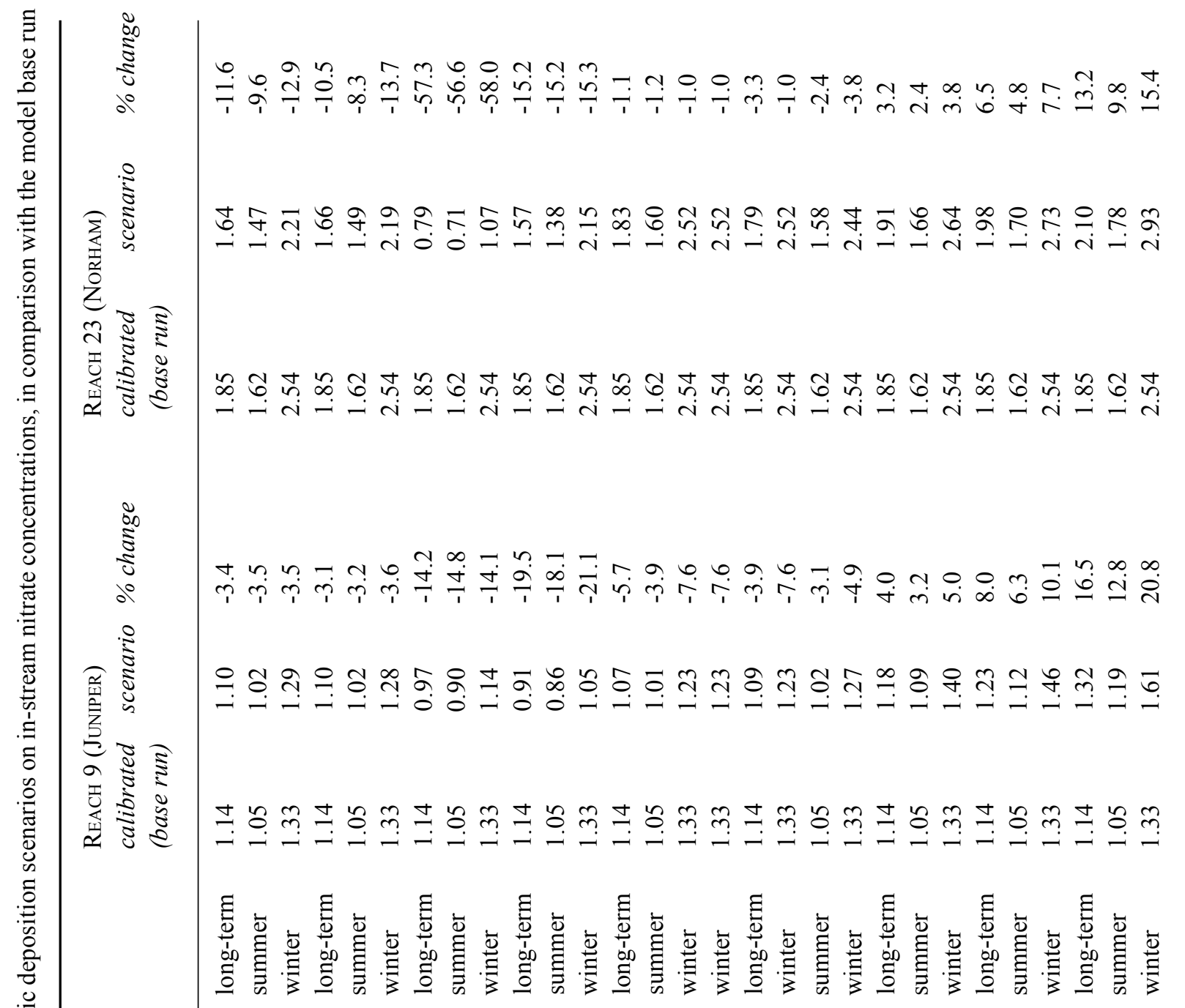

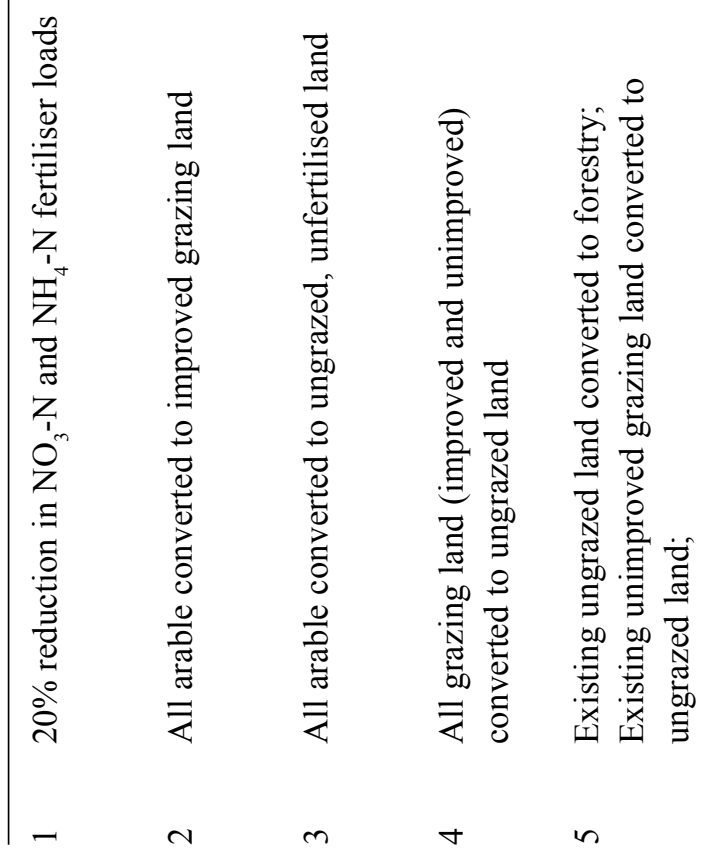

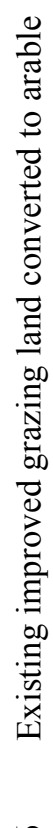

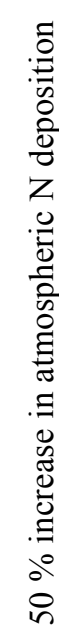

N

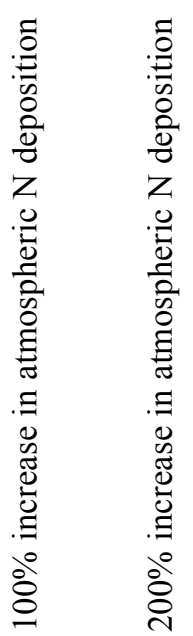

$\infty$ 


\section{Discussion}

In this study, INCA has been applied to a large-scale spatially heterogeneous catchment over a period of seven years, during which there has been a high degree of variability in climatic conditions and river flows. Model calibration was undertaken for the first four years of the data record (1994 to 1997), which incorporated periods of summer drought, the most notable of which occurred in the summer of 1995 , resulting in extremely low summer/autumn baseflow conditions. In contrast, the model test period (1998 to 2000) included periods of high summer HER, especially during 1998. The ability of INCA to reproduce broad-scale seasonal dynamics in flow and nitrate concentrations at key sites during these changing river flow conditions suggests that the predominant processes controlling river water nitrate concentrations have been represented successfully within the model. However, the variability in model fit along the river reaches and through time highlights considerable local variability in processes controlling the leaching and transport of nitrogen along the catchment-river continuum.

Extreme summer baseflow conditions during the model calibration phase had important implications for the lowermost reach of the river Tweed (Norham). Observed nitrate concentrations during the summer and autumn periods of 1994 and 1995 (Fig. 5) were significantly lower than simulated baseflow nitrate concentrations at Norham, suggesting that in-stream processes removing nitrate were operating. Long water residence times and a wide, shallow channel cross-section in the lower reaches of the River Tweed promote in-stream plant growth during these extreme summer baseflow conditions in both the main stem and lowland agricultural tributaries. In 1995, low river flows, combined with high river water temperatures $\left(20-25^{\circ} \mathrm{C}\right)$ and sunlight resulted in prolific filamentous green algal growths from Ettrick Foot to the tidal limit. The lower reaches of Whiteadder, Teviot and Leet were also affected. Intense rates of plant growth resulted in maximum values of $\mathrm{pH}$ of 10.00 10.35 , with dissolved oxygen $\%$ saturation up to $254 \%$ (Tweed River Purification Board, 1996). Rapid plant growth and biomass production can result in rapid uptake of nitrate from river water (Svendsen and Kronvang, 1993, Saunders and Kalff, 2001), and this may play a key role in controlling the downstream nitrate flux and concentration reductions observed in the Tweed in the summer-autumn periods during 1994 to 1996 . The model fit at Norham was much better during the wetter summers of the model test period (1998 to 2000), when observed nitrate concentrations were significantly higher (Fig. 9). This may reflect higher river flows or poorer growth of aquatic plants and thus reduced in-stream nitrate uptake by plants. These results suggest that, for applications of INCA to slow-flowing lowland eutrophic rivers, the possibility of incorporating a plant uptake component needs to be investigated. Plant uptake parameters will be variable through space and time, and linked to factors such as differences in reach morphology, water residence times and solar radiation.

While seasonal variability in nitrate concentrations was well represented by model simulations, more short-term variations, linked to individual predicted storm events were less accurate. Extremely high flows and associated intermittent high nitrate concentrations were often poorly simulated. This may be a result of the heterogeneity of response of source mobilisation to individual storm events, linked to differences in nitrate source availability in both time and space and delivery pathways.

However, INCA was successful in simulating downstream average spatial variations in flow and nitrate concentrations, including the effects of flow and nitrate inputs from major tributaries. The model simulations provide valuable clues about key sources of nitrogen within the catchment and their variability in time and space. The simulations demonstrated the importance of leaching from arable land to the loads of nitrate draining from the Tweed catchment (up to approximately $70 \%$ of monthly nitrate loads in 1995). Significant increases in river water nitrate fluxes correspond to the transition from the upland to the lowland parts of the catchment, linked to a shift in land use from predominantly unimproved grassland to arable. Highest leaching loads for all vegetation types occurred during the winter high flows, and leaching loads are closely linked to the timeseries of HER and thus runoff generation, with lower summer leaching loads linked to lower rates of runoff generation and biological uptake of $\mathrm{N}$. Analysis of seasonal patterns in simulated nitrate leaching loads suggests that the percentage contributions of agriculture and improved grassland to instream nitrate loads increase during the summer, and these are linked to higher contributions from unimproved grassland during the winter. Unimproved grassland is the predominant land-use type in the upper catchment and increases in nitrate leaching from unimproved grassland relative to agriculture and improved grassland may reflect greater runoff generation and nitrate delivery from the upper catchment during the winter months.

Simulated model responses to environmental change scenarios suggest possible catchment responses to perturbations in land use or atmospheric nitrogen inputs. However, caution must be exercised in evaluating model predictions, owing to the complex nature of the catchment system and the multitude of possible feedback processes in the real world, not included within the INCA model. During calibration, the parameters are fixed, which implies that the 
relationships between soil nitrogen transformation processes are fixed. As nitrogen processes respond to environmental change, it would be expected that the relationships would change and, therefore, the simulation results of future scenarios must remain tentative. Potential process responses to environmental changes require thorough investigation through field and laboratory studies. Land use scenarios linked to implementation of Nitrate Sensitive Areas recommendations have greatest impact in the lower river reaches; a $20 \%$ reduction in fertiliser inputs is predicted to result in average reductions of $12 \%$ in-stream nitrate concentration at Norham. However, by allowing all arable land to revert to its semi-natural state (ungrazed, unfertilised grassland), INCA predicts an average nitrate reduction at Norham of $57 \%$. Land use changes associated with dramatic reductions in livestock, have greatest impact on nitrate concentrations in the upper catchment, which is dominated by livestock farming. By allowing all grazing land to revert to its semi-natural state (ungrazed, unfertilised grassland), INCA predicts an average reduction in nitrate concentrations of $20 \%$ at Juniper (Reach 9). Atmospheric deposition scenarios similarly have greatest impact in the upper Tweed catchment, with an average $4 \%$ change in river-water nitrate concentrations for every $50 \%$ change in atmospheric nitrogen deposition. However, the impact of these scenarios of increased atmospheric deposition on the eutrophic status of the River Tweed is likely to be small. The greatest $\mathrm{NO}_{3}-\mathrm{N}$ contributions in the upper reaches are derived from diffuse-source run-off from unimproved grasssland which occurs predominantly during the winter, rather than during the summer growing season for macrophytes and filamentous green algae. However, these diffuse source increases could potentially exacerbate spring epilithic diatom growths. During the early 1980s, prolific benthic diatom growths were observed in the middle reaches of the Tweed during the spring. These diatom blooms have been attributed to greater diffuse source nutrient inputs, linked to changes in land use in the upper and middle catchment and, in particular, a shift towards winter sown cereal production and increased fertiliser usage (Clayton, 1997). Predicted changes in nitrate concentrations linked to environmental change are not uniform throughout the year. Changes in land use and atmospheric inputs tend to have greatest impact on winter nitrate concentrations, since winter runoff generation provides the main route of delivery of nitrate from the catchment to the river. This means that measures to reduce in-stream nitrate have greatest proportional effect during the winter. However, greatest risk of eutrophication occurs under summer low flows. Therefore, the scale of differences in response to environmental perturbation between winter and summer needs to be taken into account when assessing potential impacts of change. Predicted increases in nutrient inputs in response to environmental change may be buffered to some extent by enhanced aquatic plant growth and instream uptake, especially if nitrogen increases are accompanied by enhanced rates of phosphorus leaching (Neal, 2002).

\section{Concluding remarks}

INCA has been applied to the Tweed for modelling flow and seasonal nitrate dynamics over a seven-year period. The lower river reaches are susceptible to overestimation of summer/early autumn baseflow nitrate concentrations during dry years and this may be linked to aquatic plant uptake effects. Consideration should now be given to incorporating a spatially and temporally variable in-stream plant uptake module for application of INCA to lowland eutrophic rivers. Short-term variability in flow and nitrate concentrations during winter storm events tends to be less accurately simulated, which may be linked to complexity of short-term runoff and source generation processes. However, INCA is successful in modelling the seasonal dynamics in nitrate concentrations and broad-scale spatial variability in nitrate concentrations from the upland region to the lowlands under a wide range of hydroclimatic conditions. The model now provides a valuable tool by which to assess contributions of different catchment sources of nitrogen in the Tweed and possible effects of future changes in catchment land use and management. The application and further development of the model in collaboration with catchment managers and policy makers is strongly encouraged.

\section{References}

Ball, S., 1993. Nitrate and the law. In: Nitrate:Processes, Patterns and Management. T.P. Burt, A.L. Heathwaite and S.T. Trudgill (Eds.), Wiley, Chichester, UK. 386-400.

Chapman, P.J., Edwards, A.C. and Cresser, M.S.,2001. The nitrogen composition of streams in upland Scotland: some regional and seasonal differences. Sci. Total Envir., 265, 6583.

Clayton, J.W., 1997. The biology of the River Tweed. Sci. Total Envir., 194/195,155-162.

Cosby, B.J., Wright, R.F., Hornberger, G.M. and Galloway, J.N., 1985a. Modelling the effects of acid deposition: assessment of a lumped parameter model of soil water and stream water chemistry. Water Resour. Res., 21, 51-63.

Cosby, B.J., Wright, R.F., Hornberger, G.M. and Galloway, G.N., 1985b. Modelling the effects of acid deposition: assessment of long-term water quality responses in a small forested cathment. Water Resour. Res., 21, 1591-1601.

Cosby, B.J., Ferrier, R.C., Jenkins, A., Emmett, B., Tietama, A. and Wright, R.F., 1997. Modelling the ecosystem effects of N deposition at the catchment scale: model of ecosystem retention and loss of inorganic nitrogen (MERLIN). Hydrol. Earth. Syst. Sci., 1, 137-158. 
Dise, N.B. and Wright, R.F., 1995. Nitrogen leaching from European forests in relations to nitrogen deposition. Forest. Ecol. Manage., 71, 153-163.

Emmett, B.A., Reynolds, B., Stevens, P.A., Norris, D., Hughes, S., Gorres, J. and Lubrecht, I., 1993. Nitrate Leaching from afforested Welsh catchments - interactions between stand age and nitrogen deposition. Ambio, 22, 386-394.

Emmett, B.A., Stevens, P.A. and Reynolds, B., 1995. Factors influencing nitrogen saturation in Sitka spruce stands in Wales, UK. Wat. Air. Soil Pollut., 85, 1629-1634.

Fertliser Manufacturers' Association, 1994. British Survey of Fertiliser Practice: Fertiliser use on Farm Crops. HMSO. London.

Fowler, D., Cape, J.N. and Unsworth, M.H., 1989. Deposition of atmospheric pollutants on forests. Phil. Trans. Roy. Soc. London, B 324, 247-265.

Fuller, R.M., 1993. The land use cover map of Great Britain. Earth Space Review, 2, 13-18.

Gustard, A., Marshall, D.C.W. and Sutcliffe, M.F., 1987. Low flow estimation in Scotland. Institute of Hydrology Report no. 101, Institute of Hydrology, UK.

Heathwaite, A.L., Johnes, P.J. and Peters, N.E., 1996. Trends in nutrients. Hydrol. Proc., 10, 263-293.

Institute of Hydrology, 1998. Hydrological data UK. Hydrometric Register and statistics, 1991-1995. Institute of Hydrology, UK.

Jakeman, A.J., Littlewood, I.G. and Whitehead, P.G., 1990. Computation of the instantaneous unit hydrograph and identifiable component flows with application to two upland catchments. J. Hydrol., 117, 273-300.

Jarvie, H.P., Whitton, B.A. and Neal, C., 1998. Nitrogen and phosphorus in east coast British rivers: speciation, sources and biological significance. Sci. Tot. Environ., 210/211, 79-109.

Johnes, P.J., 1996. Evaluation and management of the impact of land use change on nitrogen and phosphorus load delivered to surface water: the export coefficient modelling approach. $J$. Hydrol., 183, 323-349.

Leeks, G.J.L., Neal, C., Jarvie, H.P., Casey, H. and Leach, D.V., 1997. The LOIS river monitoring network: strategy and implementation. Sci. Total Envir., 194/195, 101-109.

MAFF (Ministry of Agriculture, Fisheries and Food), 1989. The nitrate sensitive areas scheme. HMSO, London.

MAFF/WOAD (Ministry of Agriculture Fisheries and Food, Welsh Office Agriculture Department), 1991. Code of Good Agricultural Practice for the protection of Water. HMSO, London.

Meteorological Office, 1981. The MORECS system. Hydrological Memorandum no. 45.

Nash, J.E. and Sutcliffe, J.V.,1970. River flow forecasting through conceptual models. Part 1a Discussion of principles. J. Hydrol., 10, 282-290.

Neal, C., 2002. Nutrient concentrations and fluxes for podzolic soils at Plynlimon, mid-Wales: implications for modelling inorganic nitrogen and phosphorus in upland UK environments. Hydrol. Earth Sys. Sci., 6., 403-420.

Neal, C., Robson, A.J., Jeffrey, H.A., Harrow, M.L., Neal, M., Smith, C.J. and Jarvie, H.P., 1997. Trace element interrelationships for the Humber rivers: inferences for hydrological and chemical controls. Sci. Tot. Environ., 194/195, 321-343.

Parkinson. R.J., 1993. Changes in Agricultural Practice. In Nitrate: Processes, Patterns and Management, T.P. Burt, A.L. Heathwaite and S.T. Trudgill (Eds.), Wiley, Chichester, UK. $386-400$
RGAR, 1997. Acid deposition in the UK 1993 - 1994. Fourth report on the Review Group on Acid Rain. Department of the Environment, London, UK. 176pp.

Robson, A.J. and Neal, C., 1997. Regional water quality of the river Tweed. Sci. Total Envir., 194/195, 173-192.

Robson, A.J., Neal, C., Currie, J.C., Virtue, W.A., Ringrose, A., 1996. The water quality of the Tweed and its tributaries. Institute of Hydrology Report No. 128, Wallingford, UK. 58pp.

Rodgers, I.R., 1993. Transport and depositional model needs for power generation. In: Pollution transport and deposition modelling. Report on the conclusions of the National Forum ICON.

Saunders, D.L. and Kalff, J., 2001. Nitrogen retention in wetlands, lakles and rivers. Hydrobiologia, 443, 205-212.

Scottish Office, 1997. Prevention of Pollution from Agricultural Sources: a Code of Good Practice. Scottish Office Agriculture, Environment and Fisheries Department. Edinburgh, Scotland.

Stewart, W.D.P., Preston, T., Peterson, H.G. and Christofi, 1982. Nitrogen cycling in the eutrophic freshwaters. Phil Trans Roy. Soc. London, B 296, 491-509.

Stoddart, J.L., 1994. Long-term change changes in watershed retention of nitrogen: its causes and aquatic consequences. In: Environmental Chemistry of lakes and reservoirs Advances in Chemistry series no. 237, L.A. Baker (Ed.). American Chemical Society, Washington DC. 223-284.

Svendsen, L.M. and Kronvang, B., 1993. Retention of nitrogen and phosphorus in a Danish lowland river system: implications for the export from the watershed. Hydrobiologia, 251, 123 135.

Tindall, C.I. and Moore, R.V., 1997. The Rivers database and the overall data management for the Land-Ocean Interaction Study Programme. Sci Total Envir., 194/195, 129-135.

Tweed River Purification Board, 1996. Tweed River Purification Board Annual Report Annual Report 1995/96. Scottish Environment Protection Agency, Galashiels, UK. 28pp.

Wade, A.J., Neal, C., Soulsby, C., Smart, R.P., Langan, S.J. and Cresser, M.S., 1999. Modelling streamwater quality under varying hydrological conditions at different spatial scales. $J$. Hydrol., 217, 266-283.

Wade, A.J., Soulsby, C., Langan, S.J., Whitehead, P.J., Edwards, A.C., Butterfield, D., Smart, R.P., Cook, Y. and Owen, R.P., 2001. Modelling instream nitrogen variability in the Dee catchment, NE Scotland. Sci. Total Envir.., 265, 229-252.

Wade, A.J., Durand, P., Beaujouan, V., Wessels, W., Raat, K., Whitehead, P.G., Butterfield, D., Rankinen, K. and Lepistö, A., 2002. A nitrogen model for European catchments: new model structure and equations. Hydrol. Earth Sys. Sci., 6, 559-582.

Whitehead, P.G., Williams, R. and Lewis, D., 1997. Quality Simulation Along Rivers (QUASAR): model theory and development. Sci Total Envir., 194/195, 447-456.

Whitehead, P.G., Wilson, E.J. and Butterfield, D., 1998a. A semidistributed integrated nitrogen model for multiple source assessment in catchments (INCA): Part I, model structure and process equations. Sci. Total Envir., 210/211, 547-558.

Whitehead, P.G., Wilson, E.J, Butterfield, D. and Seed, K., 1998b. A semi-distributed integrated flow and nitrogen model for multiple source assessment in catchments (INCA): Part II, application to large river basins in south Wales and eastern England. Sci. Total Envir., 210/211, 559-583. 


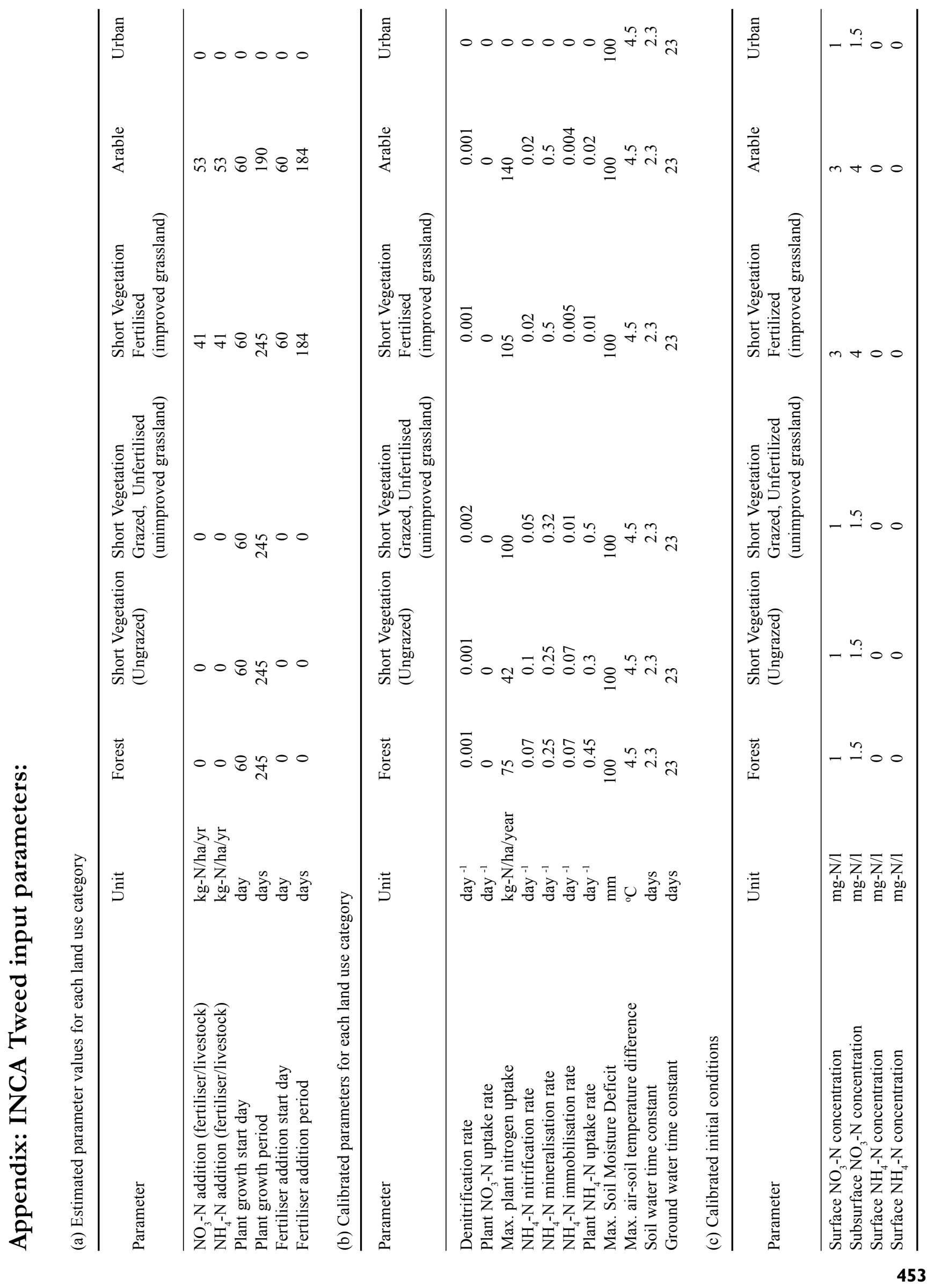


